University of Rhode Island

DigitalCommons@URI

Open Access Master's Theses

1980

\title{
A STUDY OF THE DISCRIMINATIVE STIMULUS PROPERTIES AND SOME ANALGESIC PROPERTIES OF THE NARCOTIC AGONIST- ANTAGONIST CYCLAZOCINE
}

Michael D. McCarten

University of Rhode Island

Follow this and additional works at: https://digitalcommons.uri.edu/theses

\section{Recommended Citation}

McCarten, Michael D., "A STUDY OF THE DISCRIMINATIVE STIMULUS PROPERTIES AND SOME ANALGESIC PROPERTIES OF THE NARCOTIC AGONIST-ANTAGONIST CYCLAZOCINE" (1980). Open Access Master's Theses. Paper 206.

https://digitalcommons.uri.edu/theses/206

This Thesis is brought to you for free and open access by DigitalCommons@URI. It has been accepted for inclusion in Open Access Master's Theses by an authorized administrator of DigitalCommons@URI. For more information, please contact digitalcommons-group@uri.edu. 


\section{A STUDY OF THE DISCRIMINATIVE STIMULUS PROPERTIES AND SOME ANALGESIC PROPERTIES OF THE NARCOTIC AGONIST-ANTAGONIST CYCLAZOCINE BY MICHAEL D. MCCARTEN}

A THESIS SUBMITTED IN PARTIAL FULFILLMENT OF THE REQUIREMENTS FOR THE DEGREE OF MASTER OF SCIENCE IN PHARMACOLOGY AND TOXICOLOGY 
THE CYCLAZOCINE DISCRIMINATIVE STIMULUS 


\section{MASTER OF SCIENCE THESIS}

OF

MICHAEL D. MCCARTEN

Approved:

Thesis Committee:

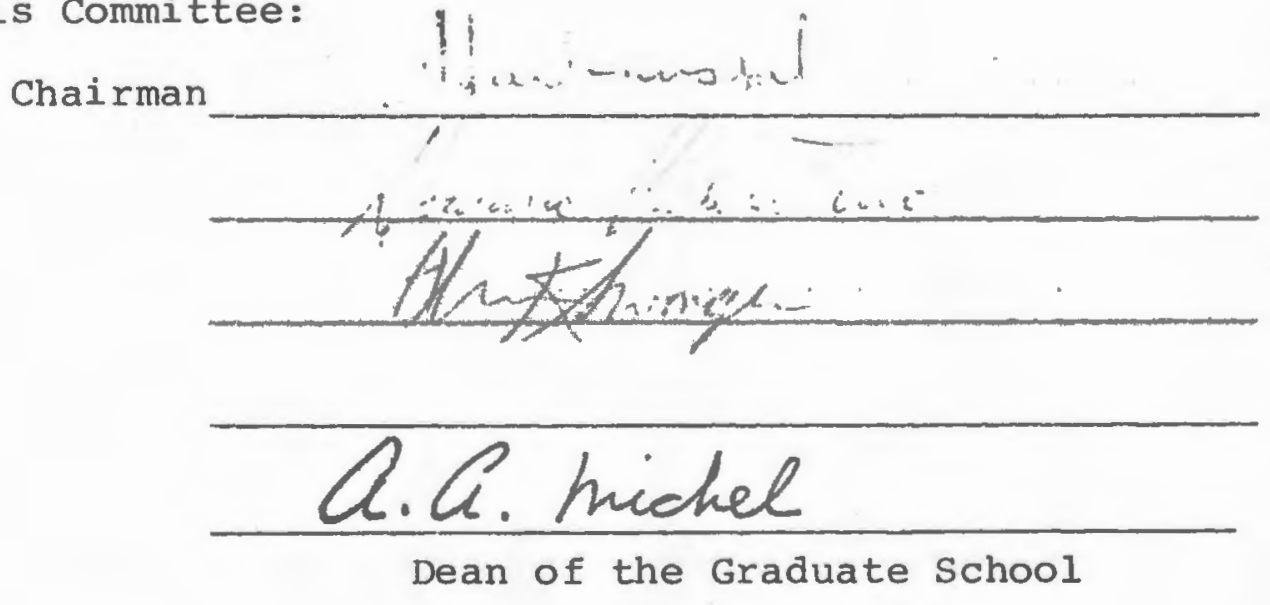

UNIVERSITY OF RHODE ISLAND 
ABSTRACT

Separate groups of rats were trained to discriminate the narcotic agonist-antagonist, cyclazocine (1.25 mg/kg), from saline or the pure narcotic agonist, morphine (10 mg/kg), from saline. In the cyclazocine discriminating animals, the interoceptive stimuli produced by cyclazocine were found to be dose related and largely based on central opiate systems in that these effects were reversed by the narcotic antagonist, naloxone. The discriminative stimulus produced by cyclazocine was found to be completely generalized to nalorphine, ethylketocyclazocine, pentazocine and morphine while a lesser degree of generalization was seen to the experimental compounds, U-49,274A and U-50,788E. The cyclazocine discriminative stimulus did not generalize to apomorphine, d-amphetamine, haloperidol, d-butaclamol, 1-butaclamol, clonidine, desipramine, amitriptyline, aceperone and butorphanol. Cyclazocine generalization to morphine was completely antagonized by naloxone at a dose one-twentieth that required to antagonize the cyclazocine discriminative stimulus itself. At no dose tested did naloxone completely antagonize cyclazocine generalization to nalorphine. A possible dopaminergic component of the cyclazocine discriminative stimulus was demonstrated by attenuation of stimulus strength with the neuroleptics haloperidol, benperidol and d-butaclamol. 
The discriminative stimulus produced by morphine was also found to be a dose related effect based upon central opiate mechanisms as demonstrated by naloxone reversibility. The discriminative stimulus produced by morphine only partially generalized to cyclazocine and ethylketocyclazocine. Naloxone antagonized the generalization of morphine to cyclazocine but at a dose four times that required to antagonize the morphine discriminative stimulus itself. A possible dopaminergic component of the morphine discriminative stimulus was demonstrated by haloperidol attenuation of stimulus strength.

Cyclazocine analgesia, demonstrated using the mouse tail flick procedure, was found to be maximal approximately five minutes following cyclazocine administration. Some analgesic potency was also measurable 35 minutes post cyclazocine. The analgesic effects of cyclazocine were found to be reversed by naloxone. Pretreatment with the neuroleptics oxiperomide, clozapine and dexclamol before cyclazocine was found to enhance the analgesic potency of cyclazocine. 
This work is dedicated to my mother, for her much needed love and support, and to my father, for being a neverending source of inspiration. 


\section{ACKNOWLEDGEMENTS}

The guidance provided by Dr. Harbans Lal during the course of these studies is sincerely appreciated. The author wishes to convey his appreciation to the members of his committee and the faculty of the Department of Pharmacology \& Toxicology of the University of Rhode Island. The author is also grateful for the help and understanding provided by his fellow students in the Department of Pharmacology and Toxicology.

The author wishes to thank Mrs. Edith Williams for typing this manuscript.

The author acknowledges the financial support provided by a Teaching Assistantship from the Department of Pharmacology \& Toxicology. 
ABSTRACT

ACKNOWLEDGEMENTS .

TABLE OF CONTENTS

INTRODUCTION. • • • • . . . . . . . . . . . . . 1

LITERATURE SURVEY • • • • . . . . • . • . . . . . 4

A. Multiple forms of opiate receptors. . . . . . . . 4

B. Ciinical use of cyclazocine . . . . . . . . . 8

C. Cyclazocine analgesia . . . . . . . . . . . 12

D. Cyclazocine effects upon animal behavior. . . . . 13

E. Discriminative stimulus proeprties of cyclazo-

F. Discriminative Stimulus Produced by Narcotic Drugs .................. . 18

METHODS AND MATERIALS • . . . . . . . . . . . . 21

A. Animals . . . . . . . . . . . . . . . . 21

B. Drugs . . . . . . . . . . . . . . . . . 21

C. Equipment . . . . . . . . . . . . . . . 22

D. Training Procedure. . . . . . . . . . . . 22

E. Testing Procedure . . . . . . . . . . . . . 24

F. Analgesia Testing . . . . . . . . . . . . 25

RESULTS • • • • • • . • . . • • • • • • • • . 27

A. Training. . . . . . . . . . . . . . . . 27

B. Generalization-Cyclazocine discriminative stimulus............... . . . . . 27

C. Naloxone blockade of cyclazocine discriminative stimulus.............. . . . . 35

D. Effects of neuroleptics upon the cyclazocine discriminative stimulus... . . . . . . 37

E. Effects of D-amphetamine upon the cyclazocine discriminative stimulus . . . . . . . . . . 43

F. Generalization - morphine discriminative stimulus 43

G. Naloxone blockade of morphine discriminative stimulus. . . . . . . . . . . . . . . 45

H. Effects of neuroleptics upon the morphine discriminative stimulus. . . . . . . . . . . .

I. Cyclazocine analgesia - Mouse tail flick. . . . 49 
PAGE

J. Effects neuroleptic pretreatment upon cyclazocine analgesia. . . . . . . . . . . 53

DISCUSSION. • • • • • • • • • • • • • • • • • • 57

CONCLUSIONS • • • . . . . . . . . . . . . . . . . . 62

BIBLIOGRAPHY. . . . . . . . . . . . . . . . . 64

vi i 


\section{LIST OF TABLES}

TABLE

PAGE

1 Number of trials required to meeting testing criterion in animals trained to discriminate cyclazocine from saline. . . . . . . . . .

2 Response rates for animals trained to discriminate cyclazocine from saline . . . . . . . .

3 Generalization of the discriminative stimulus produced by cyclazocine to narcotic drugs. . . .

4 Generalization of the discriminative stimulus produced by cyclazocine to non-narcotic psychoactive drugs . . . . . . . . . . . . . .

5 Antagonism of discriminative stimulus produced by cyclazocine by naloxone . . . . . . . . .

6 Antagonism of cyclazocine discriminative stimulus generalization to morphine by naloxone . . .

7 Antagonism of cyclazocine discriminating stimulus generalization to nalorphine by naloxone. .

8 Effects of neuroleptic pretreatment upon discriminative stimulus produced by cyclazocine. .

9 Effects of neuroleptic pretreatment upon discriminative stimulus produced by cyclazocine . .

10 Effects of d-amphetamine pretreatment upon the discriminative stimulus produced by cyclazocine.

11 Response rates for animals trained to discriminate morphine from saline. . . . . . . . . .

12 Generalization of the discriminative stimulus produced by morphine to narcotic drugs . . . .

13 Antagonism of discriminative stimulus produced by morphine by naloxone . . . . . . . . . .

14 Antagonism of morphine discriminative stimulus generalization to cyclazocine by naloxone. . . .

15 Generalization of the discriminative stimulus produced by morphine to non-narcotic psychoactive drugs... . . . . . . . . . . . 
16 Effects of haloperidol pretreatment upon the discriminate stimulus produced by morphine. . . . 52

17 Effects of naloxone upon cyclazocine analgesia using mouse tail flick procedure. . . . . . . . 54

18 Effects of neuroleptic pretreatment upon cyclazone analgesia . . . . . . . . . . . 55 


\section{INTRODUCTION}

Cyclazocine is a narcotic agonist-antagonist of the benzomorphan series which was first synthesized in the 1950s as part of a search for a nonaddicting narcotic analgesic. $\mathrm{CY}_{Y}-$ clazocine possesses narcotic agonistic activity and acts as an antagonist to many of the actions of morphine and other narcotic agonists. Based on its agonist activity, cyclazocine was considered of substantial clinical potential as an analgesic. Early clinical trials revealed that the analgesic potency of cyclazocine far surpassed that of morphine in post operative patients (LaSagna, et al., 1964). In addition, cyclazocine does not produce the euphoria which is observed following morphine administration, an effect which is believed to be the basis of narcotic addiction (Eddy et al.. 1970). As a result, cyclazocine is considered to be of low abuse potential (Martin et al., 1965).

Despite these desirable properties, clinical use of cyclazocine has been very limited due to the severity of the psychotomimetic effects which it produces (Martin et al.. 1966; Haertzen, 1970). These effects have been described as drunkenness, tiredness, anxiety and hallucinations. The neurobiological basis of these effects is unknown.

In order to experimentally evaluate the subjective effects produced by drugs, the behavioral paradigm of drug 
discrimination has been utilized in which food reinforcement is delivered to experimental animals based upon responses made on one of two levers. The lever on which responses are reinforced is determined by the injection given before responding commences. Results from such experimentation using narcotic drugs has shown that there is a high correlation between the discriminative properties of these drugs in laboratory rats and the subjective effects reported in humans (for review see Lal et al., 1977; Colpaert, 1977).

Recently, cyclazocine has been shown to produce a discriminative stimulus (Hirschhorn, 1977; Rosecrans et al.. 1978; Schaefer and Holtzman, 1978; Teal and Holtzman, 1980); however, the mechanism of this action of cyclazocine is unknown. Further experimentation dealing with the discriminative stimulus produced by cyclazocine is needed in order that the basis of the psychotomimetic effects might be determined. The present set of experiments was undertaken to investigate the nature of the discriminative stimulus produced by cyclazocine. Animals have been trained to discriminate cyclazocine from saline. They were then tested for generalization to selected narcotic agonists, narcotic agonist-antagonists and drugs which are known to affect dopaminergic systems.

Because of known similarities of characteristics between cyclazocine and narcotic agonists, another group of rats was trained to discriminate between morphine and saline to provide critical comparisons. 
In order to establish that the neuropharmacological basis of cyclazocine induced discriminative stimuli was different than the analgesic action of cyclazocine, cyclazocine induced analgesia was tested in the presence of selected neuroleptic drugs. 
II. LITERATURE SURVEY

A. Multiple Forms of Opiate Receptors

Early investigations conducted in the chronic spinal dog dealt with blockade of morphine's action with the partial agonist-antagonist, nalorphine and revealed a biphasic reversal of morphine activity with increasing doses of nalorphine. This lead to speculation that nalorphine was binding to a separate opiate receptor in the central nervous system (Martin, 1967). Elaboration of these experiments lead to the hypothesis that there were three stereochemically related opiate receptors, which were designated mu (morphine), kappa (ethylketocyclazocine) and sigma (SKF 10,047). Each of these receptor types was proposed to have separate spectrums of activity when bound by agonists for that particular receptor. Occupation of the mu receptor is characterized by miosis, bradycardia, hypothermia, depression of nociceptive responses and indifference to environmental stimuli. Kappa agonists constrict pupils, depress the flexor reflex, and produce sedation but differs from mu agonists in not altering skin twitch or pulse rate. Sigma activity is characterized by mydriasis, tachycardia, tachypnea and mania.

Based on the physiologic responses observed in the chronic spinal dog following stimulation of each of these receptors, Martin hypothesized the relative role of each 
receptor in the actions of many narcotic agents (Martin et al., 1976). Morphine has been described as having high affinity and activity at the mu and kappa receptors while having no affinity at the sigma receptor. Cyclazocine, nalorphine, pentazocine, oxilorphan and diprenorphine possess high affinity but no activity at the mu receptor while having moderate to high levels of affinity and activity at the kappa and sigma receptors. Similar results have been reported elsewhere (Pickworth and Sharpe, 1979).

In studies conducted in the rat, the similarity in binding and distribution of $\mathrm{mu}$ and kappa receptors as well as the prevention of new inactivation of these receptors by ${ }^{3} \mathrm{H}$-naltrexone and ${ }^{3} \mathrm{H}$-ethylketocyclazocine has lead to the proposal that the kappa receptor may not exist in the rat central nervous system (Hiller and Simon, 1979). This report does not dispute the existence of the three receptor types in the dog as proposed by Martin.

In morphine dependent chronic spinal dogs, the administration of the pure antagonists naloxone and naltrexone precipitated a withdrawal syndrome with the most prominent signs being hyperthermia, tachypnea, tachycardia, mydriasis and continuous stepping, in that order (Martin et al., 1974). In chronic spinal dogs made dependent on cyclazocine, similar challenge with the pure antagonists produced a syndrome with the most prominent signs being emesis, tachycardia and hyperthermia (Gilbert and Martin, 1976). In these and other 
experiments, it was found that 20 times as much naltrexone is required to precipitate cyclazocine withdrawal as is required to precipitate morphine withdrawal (Gilbert and Martin, 1976; Pickworth and Sharpe, 1979).

The abstinence syndrome which emerges four to six hours following cessation of morphine administration in the morphine dependent chronic spinal dog is suppressed by morphine and d-propoxyphene. Cyclazocine, ethylketocyclazone and ketocyclazocine failed to suppress the morphine abstinence withdrawal syndrome (Martin et al., 1976). In contrast to these results, suppression of the abstinence withdrawal in the cyclazocine dependent chronic spinal dog was observed following the administration of cyclazocine, ethylketocyclazocine, ketocyclazocine, pentazocine, morphine and nalorphine (Gilbert and Martin, 1976).

Following chronic administration of $\mathrm{N}-a l l y l$ normetrazocine, a pure sigma agonist, the administration of naltrexone or the abrupt withdrawal of drug produced syndromes characterized by enhanced flexor reflex, increased pulse rate and decreased rectal temperature. Signs which are commonly observed in the withdrawn morphine dependent or cyclazocine dependent chronic spinal dog were not observed in the $\mathrm{N}-\mathrm{al}-$ lylnormetrazocine dependent dog (Martin et al., 1979).

In addition to the three receptors proposed by Martin, a fourth type of receptor, the delta receptor, has been proposed based upon the different potencies of naloxone in 
reversing binding of labeled alkaloids and peptides in the guinea pig ileum and mouse vas deferens (Hutchinson et al., 1975; Lord et al., 1976) and guinea pig brain (Lord et al.., 1977). Results from these experiments indicate that morphine and morphine-like agonists are more potent in the guinea pig ileum, that naloxone readily reverses their effects in the guinea pig ileum and mouse vas deferens and that these types of agents more readily displace ${ }^{3} \mathrm{H}$-naloxone, ${ }^{3} \mathrm{H}$-naltrexone or ${ }^{3} \mathrm{H}$-dihydromorphine than ${ }^{3} \mathrm{H}$-enkephalin (Beaumont and Hughes, 1979). The receptors involved have been characterized as being similar to the mu receptor proposed by Martin (Martin et al., 1976). Conversely, enkephalin and enkephalin analogues have been described as delta agonists in that their effects are more pronounced in the mouse vas deferens, are not readily reversed by naloxone and are more efficient in displacing ${ }^{3} \mathrm{H}$-enkephalins as opposed to ${ }^{3} \mathrm{H}$-naloxone or ${ }^{3} \mathrm{H}$-naltrexone (Beaumont and Hughes, 1979). Beta-endorphin has been found to be equipotent as an inhibitor of ${ }^{3} \mathrm{H}$-enkephalin and ${ }^{3} \mathrm{H}$-naloxone in the guinea pig ileum and mouse vas deferens assays (Lord et al., 1977). While it is generally agreed that the mu and delta receptors exist and that these two receptors show specificity for alkaloids and enkephalins, respectively (Lord et al., 1977; Chang and Cuatracasas, 1979), it has been proposed that the differential binding of alkaloid agonist and antagonists may be due to changes in the conformation of a single 
receptor type (Smith and Loh, 1980). Such a proposal stems from the demonstration that sodium, added to incubation medium in binding assays, causes a potentiation of narcotic antagonist binding (Pert and snyder, 1974) while also causing an inhibition of agonist binding (Simon_et_al., 1973).

Treatment of tissues by the sulfhydryl blocker N-ethylmaleimide (NEM) caused a destruction of the opiate receptor (Simon et al., 1973; Terenius, 1973). This effect followed first order kinetics which suggets that one receptor was prevented by agonists, antagonists or pretreatment with sodium (Simon and Groth, 1975).

\section{B. Clinical Use of Cyclazocine}

Cyclazocine is a narcotic agonist-antagonist of the benzomorphan series, the clinical use of which is based upon its blockade of opiate receptors in the mammalian central nervous system. Cychlazocine has therefore been employed in maintenance programs for patients physically dependent on narcotics (Chappel et al., 1974; Freedman et al.., 1968; Kleber et al., 1974; Martin et al., 1966; Resnick et a1., 1974). Cyclazocine itself is considered to be of low abuse potential (Martin et al., 1965).

Acute administration of cyclazocine to naive human subjects produces analgesia, miosis, respiratory depression and constipation (Laskowitz et al., 1972), as well as dysphoric sensations described as tiredness, moodiness, misery, anxiety, hallucinations and drunkenness (Martin et al., 1966; Haertzen, 1970). 
Analgesia following $2 \mathrm{mg}$ of cyclazocine is described as being equally if not more potent than $10 \mathrm{mg}$ of morphine. Following repeated administration of cyclazocine, tolerance develops to the analgesic and subjective effects but tolerance to the narcotic antagonistic properties of cyclazocine is not observed (Martin et al., 1966).

Chronic administration of cyclazocine results in physical dependence as evidenced by the observation of an abstinence syndrome following abrupt withdrawal of the drug (Martin et al., 1965). The signs of cyclazocine withdrawal include rhinorrhea, lacrimation, hyperthermia and mydriasis. While similar signs are observed during morphine withdrawal, cyclazocine withdrawal syndrome is considered to be qualitatively different from the morphine withdrawal syndrome in that the latter includes dramatic increases in blood pressure and respiratory rate while cyclazocine withdrawal showed no change in either of these parameters. In addition, cyclazocine withdrawal was not associated with drug seeking behavior.

The cyclazocine abstinence syndrome is not detectable until four or five days following cessation of drug and does not become maximal until the seventh day. Some signs of withdrawal persist for as long as six weeks (Martin et al., 1965).

Cyclazocine, administered to subjects physically dependent upon morphine or heroin, precipitates a withdrawal 
syndrome (Martin, 1965). If, however, the subject is a post addict, whose system is "clean" of narcotic agonists, cyclazocine administration will not produce a withdrawal syndrome nor will it produce euphoria or any effects similar to morphine or heroin, but will prevent the subsequent administration of these agonists from having any agonistic effects upon the subject. This effect of cyclazocine is reported to last for 24 hours following a dose of $4 \mathrm{mg}$. of cyclazocine as demonstrated by challenge with $15 \mathrm{mg}$ of heroin I.V. (Martin et al., 1966). A similar effect is observed for 72 hours following a cyclazocine dose of $20 \mathrm{mg}$.

The pure narcotic antagonist, naloxone, is equipotent with cyclazocine in reversing the effects of morphine. Naloxone also antagonizes the pupillary, respiratory depressant, behavioral and subjective effects of cyclazocine (Jasinski et al., 1968). Such results would indicate that the agonistic and antagonistic activities of cyclazocine are mediated at different receptors.

The dysphoric effects produced by cyclazocine prevented its use during early clinical trials (Freedman et al., 1968). It was found that these effects could be minimized if a treatment induction period of 21 days was employed during which the dose of cyclazocine was increased in a gradual manner. When naloxone $(5 \mathrm{mg} / \mathrm{kg})$ was administered in conjunction with cyclazocine, so as to minimize the subjective effects, this induction period could be reduced to four days 
(Resnick, et al., 1976). All cyclazocine treatment of post addicts was begun 14 days following the last dose of agonist so as to avoid precipitation of withdrawal.

When cyclazocine was first employed in clinical trials, few subjects remained abstinant from opiates for any extended period of time. When cyclazocine therapy was conducted simultaneously with psychotherapy and counseling, $30 \%$ to $60 \%$ of the patients were opiate free 6 to 27 months following initiation of treatment (Resnick et al., 1976; Kleber et al., 1974). After 20 months of treatment, 8.58 of those patients only receiving psychotherapy and counseling were opiate free (Resnick et al., 1980).

Current research in antagonist therapy for opiate addiction is directed toward the development of antagonists which are longer acting than cyclazocine. One aspect of cyclazocine activity which has unexpectedly been considered beneficial in clinical usage, and is being sought in long acting antagonists, is the unpleasant sensations experienced upon stopping drug administration. This quality is considered desirable in treatment of opiate addiction because it has been found that patients maintained on cyclazocine were less inclined to stop their medication without consulting medical personnel first in light of the unpleasant syndrome that would emerge. Such encounters between staff and patient has proven to be of importance in maintaining patients on such therapy (Resnick et al., 1980). 


\section{c. Cyclazocine Analgesia}

Cyclazocine, when administered to human subjects suffering from post operative or post partum pain and when administered at doses as low as $0.25 \mathrm{mg}$., produced analgesia which was described as equipotent or more potent than $10 \mathrm{mg}$ of morphine (LaSagna et al.., 1964; Laskowitz, 1972). The consistent reports from subjects of the production of severe psychotomimetic effects however, have limited the clinical use of cyclazocine (LaSagna, 1964; Martin et al.., 1965; Haertzen, 1970).

Demonstration of cyclazocine analgesia in laboratory animals initially proved to be a difficult task. The mouse tail flick procedure is a reliable method for demonstrating narcotic analgesia (Dewey et al., 1969), but it proved to be ineffective in demonstrating cyclazocine analgesia until it was shown that the analgesic effects of cyclazocine in laboratory animals reach maximum levels one to five minutes following drug administration (Dewey and Harris, 1971).

Physostigmine, itself being active in the mouse tail flick procedure, enhanced the analgesic properties of cyclazocine (Harris et al., 1969).

Increase in adrenergic tone increased the toxicity of cyclazocine and other agonist-antagonists but failed to alter the analgesic potency of cyclazocine in the mouse tail flick procedure (Dewey et al., 1970).

Using the mouse tail immersion technique, sewell and Spencer (1975) demonstrated that intracerebroventricular 
administration of 5-hydroxy tryptamine $(10 \mathrm{mg}$ ) potentiated cyclazocine analgesia while similarly administered noradrenaline $(10 \mathrm{mg})$ attenuated cyclazocine analgesia.

Intradermal administration of' ethylenediaminetetraacetic acid (EDTA) in the guinea pig produces a dose dependent nociceptive stimulus (Teiger, 1976). Cyclazocine, cyclorphan, nalorphine and pentazocine all produced a dose dependent decrease in the nociceptive response (Teiger, 1976). The slopes of the dose response curves for the narcotic agonistantagonists were relatively parallel to the dose response curves for other agonist-antagonists but were not parallel to the dose response curves for morphine and other narcotic agonists in the same analgesic assay. This latter finding agrees with previous findings that the narcotic agonistantagonists have a different analgesic profile in laboratory animals than do morphine and other agonists (Harris and Pierson, 1964; Dewey et al., 1970).

D. Cyclazocine Effects Upon Animal Behavior

As has been demonstrated in the case of morphine (Olds and Travis, 1960), the narcotic agonist-antagonists cyclazocine and pentazocine have been shown to produce a dose dependent decrease in lateral hypothalamic self-stimulation in the rat (Holtzman, 1976). This effect was dose dependently reversed by the narcotic antagonist, naloxone. Naloxone at a dose of $1.0 \mathrm{mg} / \mathrm{kg}$ produced a 30 -fold shift to the right of the morphine dose response curve. In the 
case of cyclazocine and pentazocine, however, $10 \mathrm{mg} / \mathrm{kg}$ naloxone produced only a ten-fold shift to the right of the cyclazocine and pentazocine curves.

Cyclazocine and pentazocine also produce dose-related increases in continuous avoidance behavior and locomotor activity in the rat (Holtzman and Jewett, 1972). These effects were observed over a dose range of 0.125 to $2 \mathrm{mg} / \mathrm{kg}$. Larger doses of cyclazocine ( 4 to $8 \mathrm{mg} / \mathrm{kg}$ ) were found to disrupt responding and decrease locomotor activity. Naloxone reverses the increase in avoidance behavior produced by cyclazocine but is inactive in antagonism of the stimulation of locomotor activity (Holtzman and Jewett, 1973).

stimulation of locomotor activity by the narcotic agonist-antagonist pentazocine was reversed by alpha methyl paratyrosine, indicating that pentazocine stimulation may be mediated by catecholamine release (Holtzman and Jewett, 1972). Similar experiments have not been conducted with cyclazocine.

The stimulatory effect of cyclazocine upon discriminated avoidance responding is preceded by an initial period of response inhibition (Wray, 1972). These effects upon avoidance responding were shown to be strikingly similar to the effects of LSD upon similar type behavior leading to speculation by the author that these agents may be acting through similar central mechanism.

In an investigation of drug effects upon behavior controlled by interresponse time (DRL), $d, 1$ cyclazocine at doses 
of 3 and $5.6 \mathrm{mg} / \mathrm{kg}$ produced substantial increases in response rate with concomitant decreases in number of reinforcements received. A dose of $10 \mathrm{ng} / \mathrm{kg} \mathrm{d,l} \mathrm{cyclazocine} \mathrm{disrupted} \mathrm{re-}$ sponding as compared to cyclazocine vehicle sessions (AdamCarrière et al., 1978).

Cyclazocine produces increases in response rate in pigeons trained on an FR30 F15 schedule of reinforcement (MCMillan and Harris, 1972). High doses of cyclazocine caused a decrease in responserates. I-cyclazocine was found to be 30 times more potent in this effect than d-cyclazocine.

A syndrome of animal behavior consisting of lateral head movements, pivoting on the hind paws and walking backwards has been shown to emerge in a dose dependent fashion in the rat following administration of cyclazocine, levallorphan, pentazocine, nalorphine, phencyclidine, atropine, mescaline and psilocybin but not following morphine, profodol or saline (Schneider, 1968). It is believed that observation of this syndrome is predictive of the psychotomimetic effects produced by these drugs. This bizarre behavior produced by cyclazocine and levallorphan is antagonized by apomorphine, piribedel, amphetamine, benztropine and 1-dopa (Buckett and Shaw, 1975), indicating that dopaminergic systems are involved in the production of these behaviors and suggesting dopaminergic involvement in the psychotomimetic effects produced by these drugs. 
E. Discriminative Stimulus Properties of Cyclazocine

The narcotic agonist-antagonist cyclazocine produces a discriminative stimulus which controls operant responding in the rat (Hirschhorn, 1977; Rosecrans et al., 1978; Teal and Holtzman, 1980) and the squirrel monkey (Schaeffer and Holtzman, 1978). The discriminative stimulus properties of cyclazocine are attenuated by the pure narcotic antagonist naloxone (Hirschhorn, 1977; Rosecrans et al., 1978; Schaeffer and Holtzman, 1978) but the dose of naloxone required to block the discriminative stimulus produced by cyclazocine is from four to eighty times greater than the dose of naloxone required to block the discriminative stimulus produced by morphine (Gianutsos and Lal, 1975; Hirschhorn, 1977; Rosecrans et al., 1978; Schaeffer and Holtzman, 1978).

The discriminative stimulus produced by cyclazocine generalizes to the narcotic agonist-antagonists butorphanol, oxilorphan, levallorphan (Schaeffer and Holtzman, 1978), the sigma agonist SKF 10,047 (Teal and Holtzman, 1979), ketocyclazocine (Schaeffer and Holtzman, 1978; Teal and Holtzman, 1979 ) and nalorphine (Rosecrans et al.. 1978). Naloxone reversed cyclazocine generalization to butorphanol and ketocyclazocine but was not effective in antagonizing generalization to oxilorphan or levallorphan (Schaeffer and Holtzman, 1978). Cyclazocine did not generalize to morphine, pentazocine, naloxone, nalbuphine or nalmexone (Hirschhorn, 1977; Schaeffer and Holtzman, 1978; Teal and Holtzman, 1979). 
Cyclazocine produced drug appropriate responding in rats trained to discriminate fentanyl from saline (Colpaert et al., 1976) or morphine from saline (Hirschhorn and Rosecrans, 1976; Shannon and Holtzman, 1976, 1977), although these generalizations were not complete.

Based on reports that the subjectively experienced effects produced by cyclazocine in humans are psychotomimetic in nature (Martin et al., 1965; Haertzen, 1970), several investigations have explored the possibility that the discriminative stimulus produced by cyclazocine in laboratory animals may be based upon similar central mechanisms. Results indicate that cyclazocine did not generalize to the nonopioid psychoactive drugs scopolamine, d-amphetamine, mescaline, pentobarbital or LSD (Schaefer and Holtzman, 1978; Hirschhorn, 1977), but did generalize to ketamine and phencyclidine (Teal and Holtzman, 1979). This latter effect was not antagonized by naloxone.

In rats trained to discriminate ISD from saline, cyclazocine was found to substitute for LSD, although the generalization was only partial (Hirschhorn and Rosecrans, 1976).

Pentazocine, a narcotic agonist-antagonist which produces central effects similar to cyclazocine (Martins et al.. 1976), produces a discriminative stimulus in the rat (Kuhn et al., 1976).. The discriminative stimulus strength of pentazocine is subject to attenuation by the neuroleptic, haloperidol (Appel et al., 1978). 
F. Discriminative stimulus Produced by Narcotic Drugs The narcotic analgesics, of which morphine is the prototype, are a group of centrally acting agents whose principal effects include reduction of pain sensitivity, respiratory depression and the production of a euphoric state in human subjects (Jaffe and Martin, 1975). Despite its efficacy in reducing the perception of pain, the usefulness of morphine and other narcotics has been reduced by the fact that tolerance develops to many of its central effects and that physical dependence and addictive behavior are observed following repeated administration.

Several clinical studies have indicated that the self administration of narcotics is related to the subjective effects produced by these drugs (Eddy et al., 1970; Fraser et al., 1961 .

Recently, the discriminative stimulus properties of narcotic drugs were shown to be closely related to their centrally induced subjective effects (for discussion see Lal et al., 1977; Colpaert, 1977). In an effort to determine the nature of these subjective effects, much attention has been recently directed toward mechanisms underlying the discriminative stimulus produced by narcotic drugs.

The discriminative stimulus strength of morphine (Shannon and Holtzman, 1976; Miksic and Lal, 1977) and fentanyl (Colpaert et al.. 1975) have been shown to be dose related in nature in the rat. Similarly, the morphine discriminative stimulus also generalizes to other narcotic drugs in 
a dose dependent manner (Shannon and Holtzman, 1977; Miksic et al., 1978) but does not generalize to non-narcotic psychoactive drugs (Gianutsos and Lal, 1976; Miksic et al..'

The narcotic antagonist naloxone (Gianutsos and Lal, 1976) and naltrexone (Shannon and Holtzman, 1977) produce antagonism of the discriminative stimulus properties of morphine, while not producing drug appropriate responding when injected alone.

The discriminative stimulus of morphine has been shown to be based upon central rather than peripheral mechanisms of this drug. The principal peripheral effect of morphine is decreased intestinal motility, thus leading to an antidiarrheal use of morphine (Jaffe and Martin, 1975). Loperamide, a potent antidiarrheal agent (Stokkrehx et al., 1973) which is devoid of analgesic and other mrophine-like central effects (niemegeers et al.. 1974), failed to produce drug appropriate responding when administered to animals trained to discriminate morphine from saline (Gianutsos and Lal, 1975).

It has also been demonstrated that the discriminative stimulus properties of morphine are not based upon the analgesic effects of morphine. Animals trained to discriminate morphine and then subjected to increasing doses of morphine, are still able to clearly discriminate the narcotic effect although they have become tolerant to the analgesic properties of morphine (Miksic and Lal, 1977). 
The discriminative stimulus produced by fentanyl was antagonized by pretreatment with the neuroleptic pimozide, while alpha methyl paratyrosine, azaperone, chlorpromazine or pipamperone were not effective in blocking fentanyl discrimination (Colpaert et al., 1977).

The nature of generalization of the morphine discriminative stimulus to the narcotic agonist-antagonists has recently been shown to be determined by the training dose of morphine (Shannon and Holtzman, 1979). A low training dose $(1.25 \mathrm{mg} / \mathrm{kg})$ of morphine generalized completely to the narcotic antagonist nalbuphine and d-amphetamine and partially generalized to cyclazocine while a higher training dose (5.6 $\mathrm{mg} / \mathrm{kg}$ ) only partially generalized to nalbuphine and did not generalize to d-amphetamine or cyclazocine. 
III. METHODS AND MATERIALS

A. Animals

Fourteen male hooded rats of the Long-Evans strain, random bred at the Charles River Breeding Laboratories, Wilmington, Massachusetts and weighing between 300 and 350 grams were used in the discrimination experiments. Animals were singly housed in a room thermostatically controlled at $21 \pm 1^{\circ} \mathrm{C}$ with house lights turned off between 8 P.M. and 8 A.M. Water was continuously available but food was limited to approximately 20 grams per day made available 2 to 4 hours following each daily session. Animals' weights were maintained at approximately 300 grams using this feeding schedule.

B. Drugs

Aceperone, benperidol, halopomide, haloperidol, oxiperomide and pipam perone were obtained through Janssen Pharmaceutica, Beerce, Belgium. Cyclazocine, ethylketocyclazocine and pentazocine were made available through the courtesy of Sterling wintrhop Research Laboratories, Rennsalear, New York. Dextro-amphetamine sulfate and chlorpromazine was obtained from Smith, Kline and French Inc., Philadelphia, Pennsylvania. Endo Laboratories of Garden City, New York generously provided naloxone hydrochloride. D-butaclamol, 
1-butaclamol and dexclamol were supplied by Ayerst Laboratories of Montreal, Canada. Nalorphine hydrochloride and amitriptyline were obtained from the Merck Co. Inc. The Upjohn Co. of Kalamazoo, Michigan generously provided the clozapine, U 49,274A (Phenol, m-(8-(butylmethylamino)-1,4-dioxaspiro (4.5)dec-8-yl)-hydrochloride) and $U-50,488 \mathrm{E}$ (Acetamide, 2,- (3,4dichlorophenyl)-N-methyl-N-(2-(1-pyrrolidinyl) cyclohexyl) - , trans-, monohydrochloride, hemihydrate).

C. Equipment

Experiments were conducted in standard sound attenuated lever boxes obtained from Lehigh Valley Electronics, Fogelsville, Pennsylvania. Chambers were equipped with two levers attached to one wall, placed equidistant on either side of the food cup.

Boxes were electronically programmed for responses on only one of the levers to be reinforced while responses on the opposite lever were not reinfprced. Automatic counters were used to record the number of reinforcements delivered, the number of incorrect responses made before delivery of the first reinforcement and the total number of incorrect responses made during a training session.

Forty-five milligram food pellets obtained from the P.J. Noyes Company of Lancaster, New Hampshire were used for reinforcement.

D. Training Procedure

Discrimination training sessions were conducted 
on a daily basis. Animals trained for cyclazocine discrimination were injected with either cyclazocine $(1.25 \mathrm{mg} / \mathrm{kg})$ or saline $(1 \mathrm{ml} / \mathrm{kg})$ fifteen minutes prior to being placed in the operant chambers. Animals trained for morphine discrimination were injected with either morphine $(10 \mathrm{mg} / \mathrm{kg})$ or saline $(1 \mathrm{ml} / \mathrm{kg}) 15$ minutes prior to being placed in the operant chamber. All training sessions were ten minutes long. Injection of drug or saline were alternated according to an irregular sequence of injections.

Initial training sessions were conducted on a fixed ratio of one response for a reinforcement with the reinforced lever alternated randomly. No injections were given during these initial trials. When response rates on the FRI were stabilized, the fixed ratio was gradually increased over the course of several training sessions until an FRIO was reached. At this point drug and saline injections were begun. Each animal was assigned one lever as the drug lever and the alternate lever as the saline lever. Half of the animals were reinforced on the left lever following drug administration and the right lever following saline injection. Lever assignments were opposite to this in the remainder of the animals. These lever assignments did not change for the remainder of the experiment.

Training sessions consisted of placing the animals in the lever boxes 15 minutes after drug or saline administration. Once placed in the chambers, the animals were allowed to respond. Responses on the reinforced lever were recorded 
as number of reinforcements delivered. The actual number of responses made on the reinforced lever was 10 times the number of reinforcements. A separate recording was made of the number of responses made on the non-reinforced lever before the delivery of the first reinforcement. When the first reinforcement had been delivered, this recorder was automatically deactivated.

Responses made on the non-reinforced lever throughout the training sessions were recorded separately. This included responses made on the non-reinforced lever before and after the delivery of the first reinforcement.

When animals made not more than four incorrect responses before the first reinforcement on ten consecutive training days, they were considered to meet the discrimination criterion and were used for generalization testing.

\section{E. Testing Procedure}

Testing was conducted once per week per animal in the animals which maintained proper discriminative responding. On generalization test days, animals were injected with the test drug, fifteen minutes after which they were placed in the operant chambers and allowed to complete ten responses on one of the levers. Responses on the opposite lever were also recorded. When ten responses had been recorded on either of the levers, the animal was removed from the operant chamber and returned to the home cage. The test was recorded as a drug selection or a saline selection based 
upon which lever ten responses were completed first.

Drugs being tested for blockade or potentiation of the cyclazocine or morphine discriminative stimuli were injected at a predetermined interval before injection of cyclazocine, morphine or one of the agents to which the training drugs generalized. Fifteen minutes following this second injection, a test, as describea above, was conducted.

Discrimination training was conducted between tests with each animal receiving drug and saline at least twice between tests. All tests were conducted on a day following a saline training session. Training sessions were conducted at least six days per week.

F. Analgesia Testing

Male albino mice of the CD-1 strain obtained from the Charles River Breeding Laboratories were employed in the analgesia experiments. Mice were used in this portion of the experiment due to inconsistency of cyclazocine analgesia when demonstrated in the rat. The tail flick apparatus was EMDIE model TF- 6 .

Animals were hand-held in order that their tails could be placed on the notched block so as to occlude the aperture from the photocell. Turning on the 100 watt heat lamp caused simultaneous activation of a timer. The lamp was placed $13 \mathrm{~cm}$. above the platform so that heat was directed upon the animal's tail. When the animal flicked its tail, the photocell was exposed to the light and the timer was automatically stopped. The intensity of the lamp was adjusted so that 
control latencies ranged from two to four seconds. Latencies were recorded to $0.1 \mathrm{sec}$. Animals with latencies outside of this range were always discarded from the experiment.

In measuring cyclazocine analgesia, control latencies were recorded for each animal. Cyclazocine was then administered at the predetermined doses. Tail flick latency was recorded five minutes and 35 minutes following cyclazocine administration. When investigating possible drug induced alteration of cyclazocine analgesia, the drug being employed in combination with cyclazocine was administered after control latencies were recorded. With several animals from each group, a second recording was done before cyclazocine administration to insure that pretreatment agents did not have analgesic properties themselves.

oxiperomide, haloperidol, pipamperone, halopomide (R-34-301), 1-butaclamol and aceperone were administered 60 minutes prior to cyclazocine. clozapine and dexclamol were injected 30 minutes before cyclazocine while naloxone was injected 10 minutes before cyclazocine.

Analgesic latencies were defined as those which exceeded the group control mean by more than three standard deviations. All data is recorded as percent animals tested with analgesic latencies. 
IV. RESULTS

\section{A. Training}

Animals trained to discriminate cyclazocine $(1.25$ $\mathrm{mg} / \mathrm{kg}$ ) from saline met testing criteria in $41.50 \pm 1.66$ training sessions $(n=14)$ (Table 1). Several animals were sedated by the training dose of cyclazocine and were unable to respond during several of the initial drug training sessions. Tolerance to this effect was observed in all cases within three training sessions.

In agreement with previous results (Miksic, Shearman and Lal, 1978; Miksic and Lal, 1977; Gianutsos and Lal, 1975), the morphine saline trained animals met testing criteria in fewer than 40 training sessions.

B. Generalization-Cyclazocine Discriminative Stimulus

In animals trained to discriminate cyclazocine from saline, $100 \%$ of animals tested responded on the arug lever following administration of the cyclazocine training dose of $1.25 \mathrm{mg} / \mathrm{kg}$. The average response rate during cyclazocine training sessions was $85.3 \pm 7.4$ responses per minute $(n=14)$ (Table 2). Following saline injection ( $1 \mathrm{ml} / \mathrm{kg}$ ), $100 \%$ of the animals tested responded on the saline lever. The response rate during saline training sessions was $93.6 \pm 7.3$ responses per minute $(n=14)$ (Table 2 ). 
TABLE 1. NUMBER OF TRIALS REQUIRED TO MEET TESTING CRITERION ${ }^{1}$ IN ANIMALS TRAINED TO DISCRIMINATE CYCLAZOCINE $(1.25 \mathrm{mg} / \mathrm{kg})^{2}$ FROM SALINE.

Animal No.

$$
1
$$$$
2
$$$$
3
$$

4

5

6

7

8

9

10

11

12

13

14

Mean \pm S.E.
\# Trials

\section{5}

50

42

41

39

52

46

41

47

30

35

36

42

35

$41.5 \pm 1.6$

1. Testing criterion was to not emit more than four responses on the incorrect lever before the first reinforcement on ten consecutive trials.

2. Administered 15 minutes before training session. 
TABLE 2. RESPONSE RATES FOR ANIMALS TRAINED TO DISCRIMINATE CYCLAZOCINE FROM SALINE

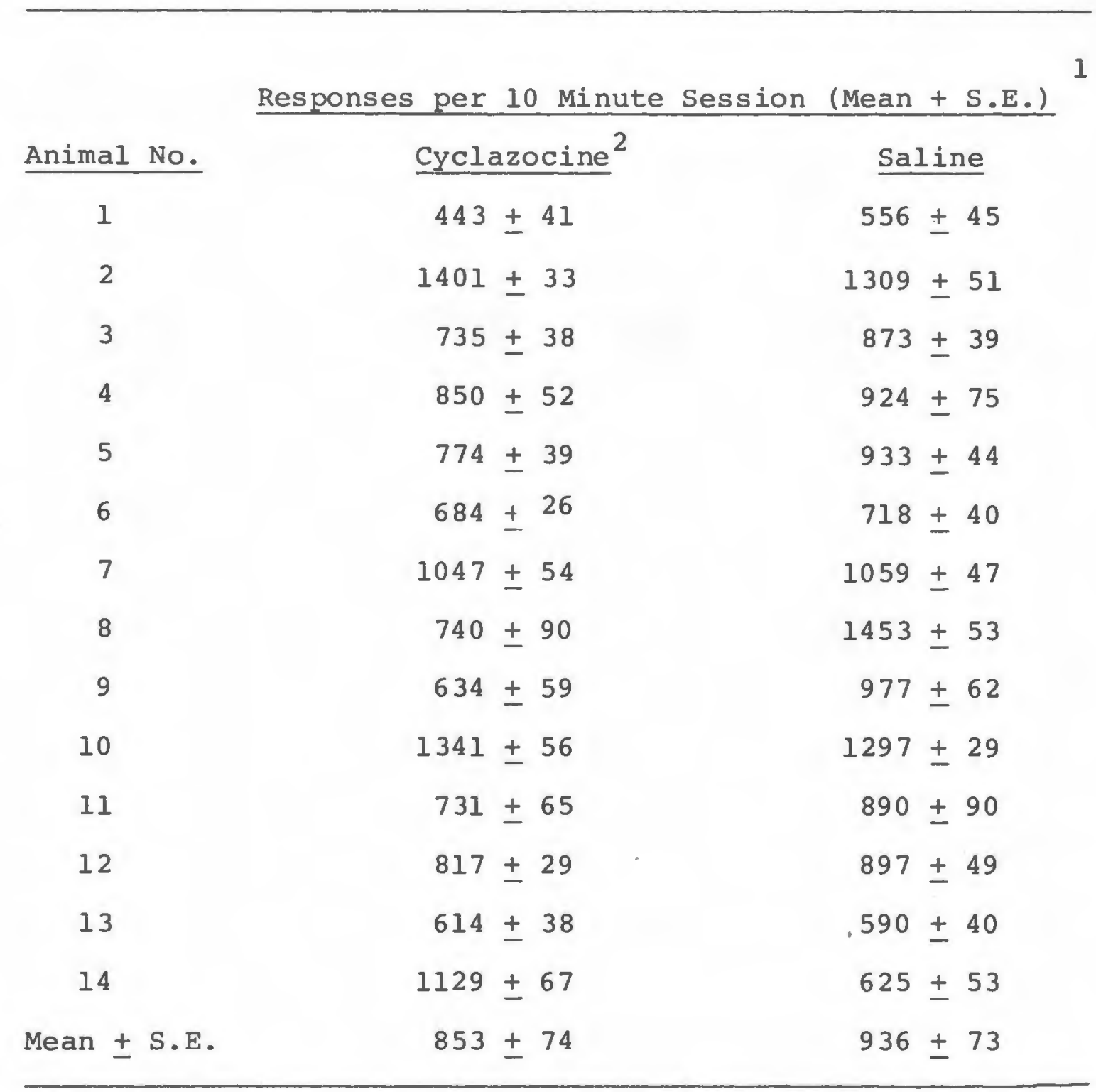

1. Based on 10 consecutive determinations commencing on day 150 of the experiment.

2. $1.25 \mathrm{mg} / \mathrm{kg}$, administered $15 \mathrm{~min}$. before measurement. 
Injection of the cyclazocine vehicle, 0.38 tartaric acid resulted in 1008 saline lever selection with response rate being similar to those observed following saline.

When the dose of cyclazocine was decreased on a log dose basis, a dose related decrease in percent animals selecting the drug lever was recorded ( $r=0.91)$ (Table 3).

Following administration of the partial agonist antagonist ethylketocyclazocine, rats trained to discriminate cyclazocine from saline selected the drug lever in a dose dependent fashion ( $r=0.91$ ) (Table 3). One hundred percent of the animals tested selected the drug lever following ethylketocyclazocine $0.32 \mathrm{mg} / \mathrm{kg}$.

The narcotic agonist-antagonist pentazocine produced dose related increases in percent animals selecting the drug lever with $100 \%$ selecting the drug lever following a dose of $20 \mathrm{~m} / \mathrm{gkg}$. Increasing the pentazocine dose to $40 \mathrm{mg} / \mathrm{kg} \mathrm{re}-$ sulted in a decrease in the ratio of animals selecting the drug lever with $70 \%$ selecting the drug lever following this dose (Table 3).

$\mathrm{U}-49,274 \mathrm{~A}$ and $\mathrm{U}-50,488 \mathrm{E}$, experimental narcotic agonistantagonists produced by the Unjohn Company, each produced drug lever selection. The highest dose of U-49,274A tested $(40 \mathrm{mg} / \mathrm{kg}$ ) resulted in 408 drug lever selection with $60 \%$ of the animals tested unable to respond. No higher doses were tested.

The highest percent animals selecting the drug lever following $U-50,488 \mathrm{E}$ was $50 \%$ following $10 \mathrm{mg} / \mathrm{kg}$ with percent 
TABLE 3. GENERALIZATION OF THE DISCRIMINATIVE STIMULUS PRODUCED BY CYCLAZOCINE $(1.25 \mathrm{mg} / \mathrm{kg})$ TO NARCOTIC DRUGS ${ }^{1}$

\begin{tabular}{|c|c|c|c|c|c|}
\hline \multirow[b]{2}{*}{ Drug } & \multirow[b]{2}{*}{ Dose } & \multirow[b]{2}{*}{$\mathrm{N}$} & \multirow[b]{2}{*}{$\begin{array}{c}\text { \& Selecting } \\
\text { Cyclazocine Lever }\end{array}$} & \multicolumn{2}{|c|}{$\begin{array}{l}\text { Responses on Unselected Lever } \\
\text { Before First Reinforcement } \\
\text { (Mean } \pm \text { S.E.) }\end{array}$} \\
\hline & & & & $\begin{array}{c}\text { Following } \\
\text { Drug Selection }\end{array}$ & $\begin{array}{c}\text { Following } \\
\text { Saline Selection } \\
\end{array}$ \\
\hline \multirow[t]{7}{*}{ CYCLAZOCINE } & 0.005 & 9 & 0 & No arug selection & \\
\hline & 0.02 & 16 & 25 & $0.38+0.38(16)$ & $1.58 \pm 0.80 \quad(12)$ \\
\hline & 0.08 & 11 & 27 & 0 & 0 \\
\hline & 0.32 & 8 & 32 & $1.67 \pm 0.88 \quad(5)$ & $1.60+1.60$ (5) \\
\hline & 0.64 & 15 & $87 *$ & $0.23 \pm 0.23$ (13) & 0 \\
\hline & 1.25 & 14 & 100 * & 0 & No saline selection \\
\hline & 2.50 & 7 & $100 *$ & 0 & No saline selection \\
\hline \multirow[t]{3}{*}{ ETHYLKETOCYCLAZOCINE } & 0.08 & 6 & 17 & 0 & $2.40 \pm 1.36 \quad(5)$ \\
\hline & 0.16 & 4 & 25 & 0 & 0 \\
\hline & 0.32 & 4 & $100 *$ & $2.50 \pm 1.66 \quad(4)$ & No saline selectior \\
\hline \multirow[t]{3}{*}{ NALORPHINE } & 0.64 & 4 & 25 & 0 & $2.33 \pm 2.33 \quad(3)$ \\
\hline & 2.50 & 7 & 43 & $2.67 \pm 2.19 \quad(3)$ & $1.50 \pm 0.63$ (4) \\
\hline & 10.00 & 8 & $100 *$ & $1.13+0.74 \quad(8)$ & No saline solution \\
\hline
\end{tabular}




\begin{tabular}{|c|c|c|c|c|c|}
\hline \multirow[b]{2}{*}{ Drug } & \multirow[b]{2}{*}{ Dose } & \multirow[b]{2}{*}{$\mathrm{N}$} & \multirow[b]{2}{*}{$\begin{array}{c}\text { \& Selecting } \\
\text { Cyclazocine Lever }\end{array}$} & \multicolumn{2}{|c|}{$\begin{array}{l}\text { Responses on Unselected Lever } \\
\text { Before First REinforcement } \\
\text { (Mean } \pm S . E .)\end{array}$} \\
\hline & & & & $\begin{array}{c}\text { Following } \\
\text { Drug selection }\end{array}$ & $\begin{array}{l}\text { Following } \\
\text { Saline selection }\end{array}$ \\
\hline \multirow[t]{4}{*}{ PENTAZOCINE } & 2.50 & 7 & 14 & $1.00 \pm 0 \quad(1)$ & 0 \\
\hline & 10.00 & 5 & 80 & $3.25 \pm 1.18 \quad(4)$ & $9.0 \pm 0 \quad(1)$ \\
\hline & 20.00 & 5 & 100 & $1.20 \pm 1.20 \quad(5)$ & saline selection \\
\hline & 40.00 & 10 & 70 & $1.43 \pm 0.69 \quad(7)$ & $2.33 \pm 1.86 \quad(3)$ \\
\hline \multirow[t]{2}{*}{$\mathrm{U}-49,274 \mathrm{~A}$} & 20.00 & 8 & 25 & $3.00 \pm 2.45 \quad(2)$ & $3.17 \pm 1.62(6)$ \\
\hline & 40.00 & 5 & 60 & 0 & $5.67 \pm 1.86 \quad(3)$ \\
\hline \multirow[t]{3}{*}{$\mathrm{U}-50,488 \mathrm{E}$} & 2.50 & 5 & 20 & $5.00 \pm 0 \quad(1)$ & $0.50 \pm 0.29$ (4) \\
\hline & 10.00 & 8 & 50 & 0 & $2.00+1.35 \quad(4)$ \\
\hline & 20.00 & 4 & 25 & $8.00+0 \quad(1)$ & 0 \\
\hline \multirow[t]{3}{*}{ MORPHINE } & 2.50 & 6 & 17 & 0 & $1.60 \pm 1.36 \quad(5)$ \\
\hline & 5.00 & 8 & 50 & $1.75 \pm 0.85 \quad(4)$ & 0 \\
\hline & 10.00 & 6 & 100 & $3.67 \pm 1.65$ (6) No & saline selection \\
\hline \multirow[t]{3}{*}{ NALOXONE } & 0.16 & 7 & 0 & No drug selection & 0 \\
\hline & 10.00 & 9 & 0 & No drug selection & $0.40 \pm 0.24$ (5) \\
\hline & 40.00 & 5 & 0 & No drug selection & 0 \\
\hline
\end{tabular}

$\mathrm{I}_{\mathrm{All}}$ drugs and doses administered 15 minutes prior to testing.

*Statistically significant difference $(P \leq 0.05)$ by Fisher Exact Probability in comparison with 100\% saline lever selection ( $n=14)$. 
selecting the drug lever decreasing to $25 \%$ following a dose of $20 \mathrm{mg} / \mathrm{kg}$.

The discriminative stimulus produced by cyclazocine completely generalized to the pure narcotic agonist morphine (Table 3). Dose related increases in percent selection of drug lever were observed with $100 \%$ drug lever selection following a dose of $10 \mathrm{mg} / \mathrm{kg} \quad(r=0.99)$.

The pure narcotic antagonist, naloxone, produced saline lever selection in all animals tested and at all doses tested from $0.64 \mathrm{mg} / \mathrm{kg}$ to $40.0 \mathrm{mg} / \mathrm{kg}$.

In order to investigate the possible biogenic amine basis of the cyclazocine discriminative stimulus, selected agents were tested for generalization to the cyclazocine discriminative stimulus.

The direct and indirect dopamine receptor stimulants apomorphine and d-amphetamine were tested for generalization. All doses of apomorphine tested produced saline lever selection (Table 4). In the case of d-amphetamine, a dose of 0.64 $\mathrm{mg} / \mathrm{kg}$ generalized to saline. A dose of $1.25 \mathrm{mg} / \mathrm{kg}$ resulted in two of the five animals tested selecting the drug lever. Dopaminergic receptor blockers also produced saline lever selection. The agents used in these tests included bemperidol $(0.32 \mathrm{mg} / \mathrm{kg})$, d-butaclamol $(0.16 \mathrm{mg} / \mathrm{kg})$, 1-butaclamol $(0.16 \mathrm{mg} / \mathrm{kg})$, clozapine $(5.0 \mathrm{mg} / \mathrm{kg})$, dexclamol $(0.16$ $(\mathrm{mg} / \mathrm{kg})$, haloperidol $(0.32 \mathrm{mg} / \mathrm{kg})$ and oxiperomide $(0.16 \mathrm{mg} / \mathrm{kg})$ (Table 4). 
TABLE 4. GENERALIZATION OF THE DISCRIMINATIVE STIMULUS PRODUCED BY CYCLAZOCINE $(1.25 \mathrm{mg} / \mathrm{kg})$ TO NON-NARCOTIC PSYCHOACTIVE DRUGS

\begin{tabular}{|c|c|c|c|c|c|c|}
\hline \multirow[b]{2}{*}{ Drug } & \multirow[b]{2}{*}{ Dose $(\mathrm{mg} / \mathrm{kg})$} & \multirow[b]{2}{*}{$\mathbf{N}$} & \multirow{2}{*}{$\begin{array}{l}\text { Drug } \\
\text { Lever } \\
\end{array}$} & \multicolumn{3}{|c|}{$\begin{array}{l}\text { Responses on Incorrect Lever } \\
\text { (Mean } \pm \text { S.E.) }\end{array}$} \\
\hline & & & & Drug Selection & Saline & Selection \\
\hline \multirow[t]{2}{*}{ APOMORPHINE } & 0.64 & 4 & 0 & - & $2.50 \pm 1$ & $.50 \quad(2)$ \\
\hline & 1.25 & 1 & 0 & - & & 0 \\
\hline \multirow[t]{3}{*}{ d-AMPHETAMINE } & 0.16 & 3 & 0 & - & & 0 \\
\hline & 0.64 & 7 & 0 & - & & 0 \\
\hline & 1.25 & 5 & 40 & $0.50 \pm 0.50 \quad(2)$ & $1.0 \pm 0$ & (2) \\
\hline HALOPERIDOL & 0.32 & 4 & 0 & - & & 0 \\
\hline d-BUTACLAMOL & 0.16 & 5 & 0 & - & & 0 \\
\hline 1-BUTACLAMOL & 0.16 & 6 & 0 & - & & 0 \\
\hline BENPERIDOL & 0.32 & 5 & 0 & - & & 0 \\
\hline CLOZAPINE & 5.00 & 9 & 0 & - & & 0 \\
\hline OXIPEROMIDE & 0.16 & 7 & 0 & - & & 0 \\
\hline DEXCLAMOL & 0.16 & 5 & 0 & - & & 0 \\
\hline \multirow[t]{2}{*}{ HALOPOMIDE } & 2.50 & 2 & 0 & - & & 0 \\
\hline & 10.00 & 6 & 0 & - & & 0 \\
\hline CLONIDINE & 0.16 & 4 & 0 & - & & 0 \\
\hline DESIPRAMINE & 10.00 & 9 & 0 & - & & 0 \\
\hline AMITRIPTYLINE & 30.00 & 3 & 0 & - & & 0 \\
\hline ACEPERONE & 2.50 & 5 & 20 & 0 & & 0 \\
\hline BUTORPHANOL & 0.16 & 4 & 0 & 0.75 & +0.75 & 4) \\
\hline
\end{tabular}


Halopomide (R34-301), a compound which reportedly blocks peripheral dopaminergic receptors, when tested for generalization at doses of 2.50 and $10.0 \mathrm{mg} / \mathrm{kg}$ resulted in $100 \% \mathrm{sa}-$ line lever selection.

Clonidine $(0.16 \mathrm{mg} / \mathrm{kg})$, an alpha ${ }_{1}$ adrenergic agonist, produced saline lever selection (Table 4).

The tricyclic antidepressants amitriptyline and desipramine both produced saline lever selection in all animals tested (Table 4).

Aceperone, an alpha adrenergic blocker, administered at a dose of $2.50 \mathrm{mg} / \mathrm{kg}$ produced $20 \%$ drug lever selection $(\mathrm{n}=5)$ (Table 4). Butorphanol reportedly having narcotic agonistantagonist properties produced $100 \%$ saline lever selection (Table 4).

C. Naloxone Blockade of Cyclazocine Discriminative Stimulus In agreement with previous reports (Hirschhorn, 1977; Rosecrans et al., 1978; Schaeffer and Holtzman, 1978; Teal and Holtzman, 1980), naloxone produced a dose dependent blockade of the cyclazocine discriminative stimulus (Table 5). Naloxone administered in doses of 2.5 or $10.00 \mathrm{mg} / \mathrm{kg}$ fifteen minutes prior to the cyclazocine training dose resulted in diminished percent drug lever selection. Complete blockade of the cyclazocine discriminative stimulus was observed following naloxone $40 \mathrm{mg} / \mathrm{kg}$ i.e., $100 \%$ of the animals tested selected the saline lever. 
TABLE 5. ANTAGONISM OF DISCRIMINATIVE STIMULUS PRODUCED BY CYCLAZOCINE $\left(1.25^{\prime} \mathrm{mg} / \mathrm{kg}\right)$ BY NALOXONE ${ }^{1}$

\begin{tabular}{|c|c|c|c|c|c|}
\hline \multirow[b]{2}{*}{$\begin{array}{c}\text { Naloxone } \\
\text { Dose (mg/kg) }\end{array}$} & \multirow[b]{2}{*}{$\mathbf{N}$} & \multirow{2}{*}{$\begin{array}{l}\text { \& Selecting } \\
\text { Cyclazocine } \\
\text { Lever } \\
\end{array}$} & \multicolumn{3}{|c|}{$\begin{array}{c}\text { Responses on Unselected Lever } \\
\text { Before First Reinforcement } \\
\text { (Mean } \pm \text { S.E.) }\end{array}$} \\
\hline & & & $\begin{array}{r}\text { Following Drug } \\
\text { Lever Selection } \\
\end{array}$ & $\begin{array}{l}\text { Followin } \\
\text { Lever Se }\end{array}$ & $\begin{array}{l}\text { ng Saline } \\
\text { election }\end{array}$ \\
\hline 0 & 14 & $100 *$ & 0 & No saline & selection \\
\hline 0.64 & 6 & $100 *$ & 0 & No saline & selection \\
\hline 2.50 & 5 & $60 *$ & $0.33 \pm 0.33$ (3) & & 0 \\
\hline 10.00 & 7 & 14 & 0 & $1.67 \pm 0.80$ & $(6)$ \\
\hline 40.00 & 5 & 0 & No drug selection & & 0 \\
\hline
\end{tabular}

1. Naloxone administered 15 minutes prior to cyclazocine $(1.25 \mathrm{mg} / \mathrm{kg})$

2. Statistically significant difference $\left(p^{/} 0.05\right)$ by Fisher Exact Probability in comparison with $100 \%$ saline lever selection $(n=14)$. 
Naloxone also antagonized generalization of the cyclazocine discriminative stimulus to morphine (10 mg/kg) (Table 6). Complete blockade of this generalization was achieved following naloxone $1.25 \mathrm{mg} / \mathrm{kg}$.

Generalization of the cyclazocine discriminative stimulus to nalorphine $(10 \mathrm{mg} / \mathrm{kg})$ was not completely blocked by naloxone at any dose of naloxone tested (Table 7). Although naloxone at a dose of $0.64 \mathrm{mg} / \mathrm{kg}$ reduced percent drug lever selection from $100 \%$ to $57 \%$, further increases in the naloxone dose, up to $40 \mathrm{mg} / \mathrm{kg}$, resulted in approximately $258 \mathrm{drug}$ lever selection.

D. The Effects of Neuroleptics Upon the Cyclazocine Discriminative Stimulus

In order to investigate a possible dopaminergic component in the cyclazocine discriminative stimulus, several neuroleptics were employed as pretreatments to cyclazocine before generalization testing. Initial portions of this series of experiments were conducted at the training dose of cyclazocine, $1.25 \mathrm{mg} / \mathrm{kg}$. The dosages of neuroleptics which were used in these experiments were decided upon in light of previous results in animal experimentation using these same drugs.

The neuroleptic, d-butaclamol, when administered at a dose of $0.16 \mathrm{mg} / \mathrm{kg} 60$ minutes prior to cyclazocine, produced a statistically significant attenuation of the cyclazocine discriminative stimulus (Table 8 . 
TABLE 6. ANTAGONISM OF CYCLAZOCINE DISCRIMINATIVE STIMULUS GENERALIZATION TO MORPHINE $(10 \mathrm{mg} / \mathrm{kg})$ BY NALOXONE

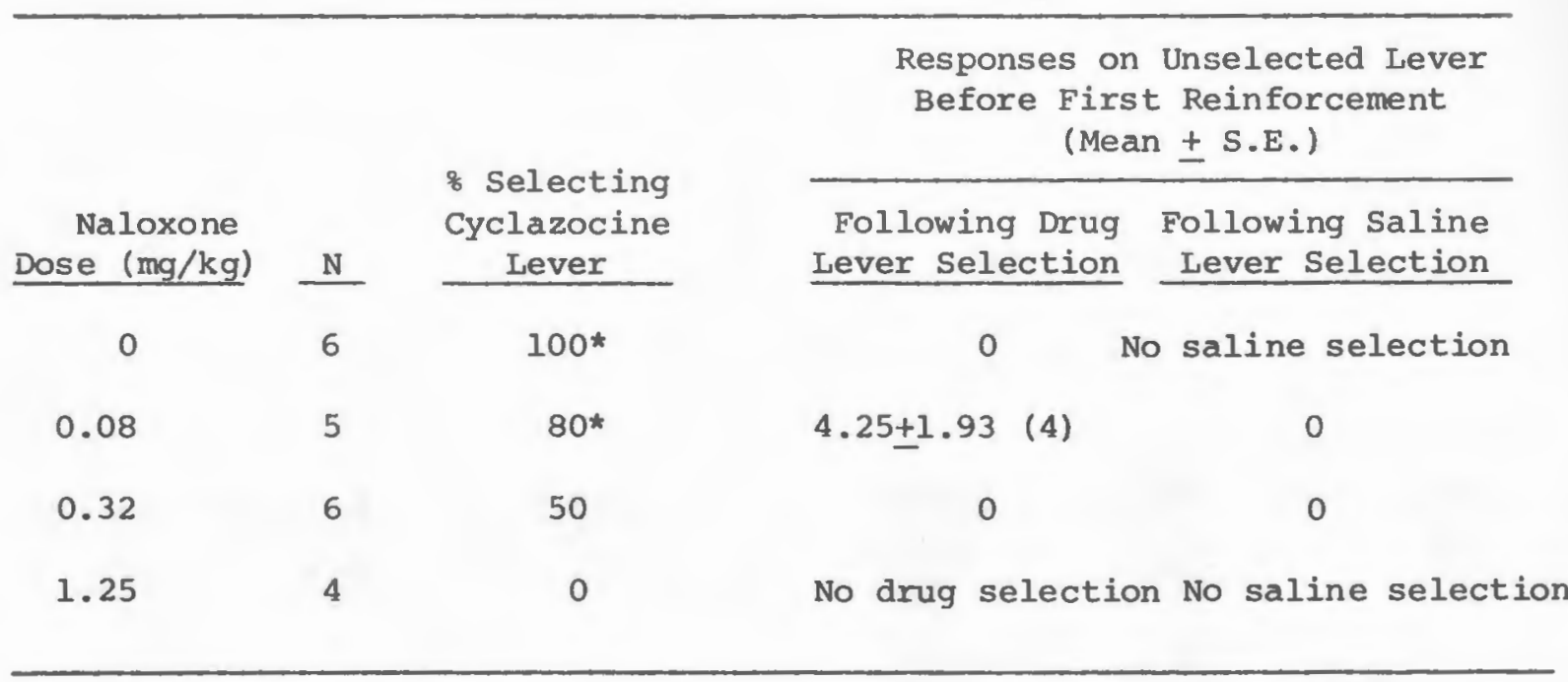

1. Naloxone administered 15 minutes prior to morphine $(10 \mathrm{mg} / \mathrm{kg})$.

* Statistically significant difference $(\mathrm{p}<0.05)$ by Fisher Exact Probability in comparison with $100 \%$ saline lever selection $(n=14)$. 
TABLE 7. ANTAGONISM OFCYCLAZOCINE DISCRIMINATING STIMULUS GENERALIZATION TONALORPHINE (10 $\mathrm{mg} / \mathrm{kg})$ BY NALOXONEl

\begin{tabular}{|c|c|c|c|c|}
\hline \multirow[b]{2}{*}{$\begin{array}{c}\text { Naloxone } \\
\text { Dose }(\mathrm{mg} / \mathrm{kg}) \\
\end{array}$} & \multirow[b]{2}{*}{$\mathrm{N}$} & \multirow{2}{*}{$\begin{array}{c}\text { Selecting } \\
\text { Cyclazocine } \\
\text { Lever } \\
\end{array}$} & \multicolumn{2}{|c|}{$\begin{array}{l}\text { Responses on Unselected Lever } \\
\text { Before First Reinforcement } \\
\text { (Mean } \pm \text { S.E.) }\end{array}$} \\
\hline & & & $\begin{array}{l}\text { Following Drug } \\
\text { Lever Selection }\end{array}$ & $\begin{array}{l}\text { Following Saline } \\
\text { Lever Selection }\end{array}$ \\
\hline 0 & 4 & 1008 & $1.13+0.74$ (8) & No saline selection \\
\hline 0.64 & 7 & 57 * & $0.25+0.25 \quad(4)$ & 0 \\
\hline 2.50 & 8 & 25 & $.3 .50 \pm 3.50 \quad(2)$ & $1.33 \pm 1.33$ (8) \\
\hline 10.00 & 8 & 38 & $2.00 \pm 1.53 \quad(3)$ & 0 \\
\hline 20.00 & 9 & 11 & 0 & 0 \\
\hline 40.00 & 8 & 25 & $3.00+3.00 \quad(2)$ & 0 \\
\hline
\end{tabular}

1. Naloxone administered 15 minutes prior to nalorphine.

* Statistically significant difference $(p<0.05)$ by Fisher Exact

- Probability in comparison with $100 \%$ saline lever selection $(n=14)$. 
TABLE 8. THE EFFECTS OF NEUROLEPTIC PRETREATMENT UPON DISCRIMINATIVE STIMULUS PRODUCED BY CYCLAZOCINE

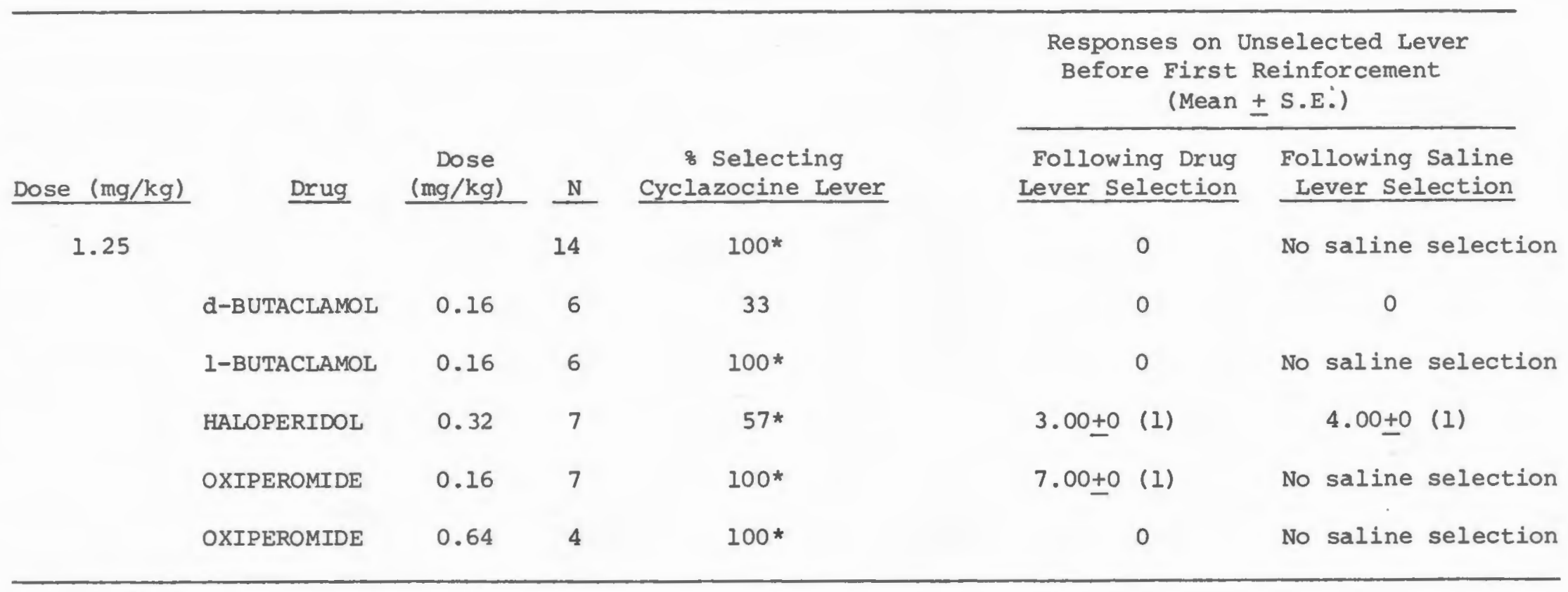

1. Neuroleptics administered one hour prior to cyclazocine $(.25 \mathrm{mg} / \mathrm{kg})$.

* Statistically significant difference $(\mathrm{p}<0.05)$ by Fisher Exact Probability in comparison with 100 \% saline lever selection $(n=14)$. 
L-butaclamol, an enantiomer devoid of neuroleptic activity, was ineffective in altering the discriminative stimulus strength of cyclazocine (Table 8).

Haloperidol $(0.32 \mathrm{mg} / \mathrm{kg})$, a member of the butyrophenone series of neuroleptics, produced a blockade of the cyclazocine discriminative stimulus which was not significantly different from saline pretreatment (Table 8 ).

Oxiperomide, a dopaminergic antagonist specifically active in the gut and at the chemoreceptor trigger zone, did not produce a blockade of the cyclazocine discriminative stimulus at either of the two doses tested $(0.16 \mathrm{mg} / \mathrm{kg})$ and $0.64 \mathrm{mg} / \mathrm{kg}$ ) (Table 8).

In view of the fact that the discriminative stimulus strength of cyclazocine at a dose of $1.25 \mathrm{mg} / \mathrm{kg}$ might represent a plateau effect at the higher ranges of the dose-response curve, and that the possible blocking properties of neuroleptics tested might be masked by such an effect, additional experiments dealing with cyclazocine discriminative stimulus blockade by neuroleptics were conducted with cyclazocine $0.64 \mathrm{mg} / \mathrm{kg}$.

In subsequent experimentation, haloperidol $(0.32 \mathrm{mg} / \mathrm{kg})$ produced a blockade of the cyclazocine discriminative stimulus which was statistically significant (Table 9). In this test, the percent animals selecting the drug lever was decreased from $87 \%(n=15)$ with no pretreatment to $18^{\circ} \quad(n=11)$ with haloperidol pretreatment. 
TABLE 9. THE EFFECTS OF NEUROLEPTIC PRETREATMENT ${ }^{1}$ UPON THE DISCRIMINATIVE STIMULUS PRODUCED BY CYCLAZOCINE

\begin{tabular}{|c|c|c|c|c|c|c|}
\hline \multirow[b]{2}{*}{$\begin{array}{l}\text { Cyclazocine } \\
\text { Dose (mg/kg) }\end{array}$} & \multirow[b]{2}{*}{ Drug } & \multirow[b]{2}{*}{$\begin{array}{c}\text { Dose } \\
(\mathrm{mg} / \mathrm{kg}) \\
\end{array}$} & \multirow[b]{2}{*}{$\mathbf{N}$} & \multirow[b]{2}{*}{$\begin{array}{c}\text { of Selecting } \\
\text { Cyclazocine Lever }\end{array}$} & \multicolumn{2}{|c|}{$\begin{array}{l}\text { Responses on Unselected Lever } \\
\text { Before First Reimforcement } \\
\text { (Mean } \pm \text { S.E.) }\end{array}$} \\
\hline & & & & & $\begin{array}{r}\text { Following Drug } \\
\text { Lever Selection }\end{array}$ & $\begin{array}{l}\text { Following Saline } \\
\text { Lever Selection }\end{array}$ \\
\hline \multirow[t]{7}{*}{0.64} & - & - & 15 & $87 *$ & $3.00 \pm 0(1)$ & No saline selection \\
\hline & BENPERIDOL & 0.32 & 5 & 20 & 0 & 0 \\
\hline & CLOZAPINE ${ }^{2}$ & 5.00 & 9 & $56 *$ & 0 & $8.00 \pm 0(3)$ \\
\hline & CLOZAPINE ${ }^{2}$ & 10.00 & 6 & $67 *$ & 0 & 0 \\
\hline & DEXCLAMOL & 0.16 & 5 & 60 & $4.00 \pm 0(1)$ & $4.00 \pm 0$ (1) \\
\hline & HALOPERIDOL & 0.08 & 9 & $100 *$ & 0 & 0 \\
\hline & HALOPERIDOL & 0.32 & 11 & 18 & 0 & 0 \\
\hline
\end{tabular}

1. Neuroleptics administered one hour prior to cyclazocine $(0.64 \mathrm{mg} / \mathrm{kg})$

2. Clozapine administered 30 minutes prior to cyclazocine.

* Statistically significant difference $(p<0.05)$ by Fisher Exact Probability in comparison with 100 saline lever selection $(n=14)$. 
A smaller dose of haloperidol was found to be ineffective in blocking the discriminative-stimulus properties of cyclazocine.

A similar attenuation of the cyclazocine discriminative stimulus was observed following pretreatment with benperidol $(0.32 \mathrm{mg} / \mathrm{kg}) 60$ minutes prior to cyclazocine $(0.64 \mathrm{mg} / \mathrm{kg})$ (Table 9).

Clozapine, a weak neuroleptic which produces few extrapyramidal side effects, was found to produce some blockade of the cyclazocine discriminative stimulus, although this effect of clozapine was not found to be statistically significant (Table 9).

Similarly, dexclamol, a soluble form of the previously mentioned butaclamol, was found to have stimulus blocking effects which were not within a statistically significant range (Table 9).

E. The Effects of D-Amphetamine Upon the Cyclazocine Discriminative stimulus

D-amphetamine $(0.64 \mathrm{mg} / \mathrm{kg})$ pretreatment fifteen minutes prior to cyclazocine administration caused no detectable change in the discriminative stimulus properties of cyclazocine (Table 10).

F. Generalization - Morphine Discriminative Stimulus

Animals trained to discriminate morphine $(10 \mathrm{mg} / \mathrm{kg})$

from saline $(1 \mathrm{ml} / \mathrm{kg}$ ) selected the drug lever 1008 of the trials following this training dose. The percent animals 
TABLE 10. THE EFFECTS OF d-AMPHETAMINE PRETREATMENT ${ }^{1}$ UPON THE DISCRIMINATIVE STIMULUS PRODUCED BY CYCLAZOCINE

\begin{tabular}{|c|c|c|c|c|c|}
\hline \multirow[b]{2}{*}{$\begin{array}{l}\text { d-Ampetamine } \\
\text { Dose (mg/kg) }\end{array}$} & \multirow[b]{2}{*}{$\begin{array}{l}\text { Cyclazocine } \\
\text { Dose (mg/kg) }\end{array}$} & \multirow[b]{2}{*}{$\mathrm{N}$} & \multirow[b]{2}{*}{$\begin{array}{l}\text { \& Selecting } \\
\text { Drug Lever }\end{array}$} & \multicolumn{2}{|c|}{$\begin{array}{l}\text { Responses on Unselected } \\
\text { Lever (Mean } \pm \text { S.E.) }\end{array}$} \\
\hline & & & & $\begin{array}{l}\text { Following Drug } \\
\text { Lever Selection }\end{array}$ & $\begin{array}{l}\text { Following Saline } \\
\text { Lever Selection }\end{array}$ \\
\hline 0.64 & 0 & 7 & 0 & - & 0 \\
\hline 0.64 & 0.02 & 7 & 14 & $1.0 \pm 0(1)$ & 0 \\
\hline 0.64 & 0.08 & 7 & 57 & $2.50 \pm 1.66$ (4) & $3.67 \pm 2.67$ (3) \\
\hline 0.64 & 0.32 & 7 & 71 & 0 & 0 \\
\hline
\end{tabular}

1. Administered 15 minutes prior to cyclazocine. 
selecting the drug lever decreased with decreases in the dose of morphine administered $(r=0.89)^{\prime}$ (Táble 11$)$.

The partial agonist-antagonist, cyclazocine, produced drug lever selection in animals trained to discriminate morphine from saline. This generalization was not complete in that at no dose tested did $100 \%$ of the animals tested select the drug lever $(r=0.90)$ (Table 12).

Ethylketocyclazocine, also a partial agonist-antagonist, produced drug lever selection in animals trained to discriminate morphine from saline (Table 12). Increases in percent animals selecting drug lever was observed when the dose of ethylketocyclazocine was increased from $0.08 \mathrm{mg} / \mathrm{kg}$ to 0.32 $\mathrm{mg} / \mathrm{kg}$. Further increases in dose to $0.64 \mathrm{mg} / \mathrm{kg}$ and 1.25 $\mathrm{mg} / \mathrm{kg}$ produced a percent drug lever selection decrease. The pure narcotic antagonist, naloxone, produced exclusive saline lever selection at all doses tested (Table 12).

G. Naloxone Blockade of Morphine Discriminative Stimulus Naloxone produced a dose dependent blockade of the morphine discriminative stimulus when administered $15 \mathrm{~min}$ utes prior to morphine injection ( $r=0.99)$ (Table 13). Complete blockade was recorded following naloxone $0.32 \mathrm{mg} / \mathrm{kg}$. When naloxone was administered 15 minutes prior to cyclazocine $(1.25 \mathrm{mg} / \mathrm{kg})$ in rats trained to discriminate morphine from saline, there was a diminished percent animals selecting the drug lever as compared to saline injection or 
TABLE 11. RESPONSE RATES FOR ANIMALS TRAINED TO DISCRIMINATE MORPHINE FROM SALINE

\begin{tabular}{|c|c|c|c|c|}
\hline & & Responses per 10 & Minute Session & $(\text { Mean } \pm \text { S.E. })^{l}$ \\
\hline Animal No. & & Morphine ${ }^{2}$ & & Saline \\
\hline 1 & ' & $832 \pm 68$ & & $1240 \pm 59$ \\
\hline 2 & & $557 \pm 50$ & & $981 \pm 85$ \\
\hline 3 & & $600 \pm 64$ & & $989 \pm 50$ \\
\hline 4 & & $748 \pm 45$ & & $1015 \pm 69$ \\
\hline 5 & & $736 \pm 77$ & $\cdot$ & $1218 \pm 46$ \\
\hline 6 & & $181 \pm 35$ & & $795 \pm 72$ \\
\hline 7 & & $682 \pm 91$ & & $1097 \pm 62$ \\
\hline 8 & & $451 \pm 49$ & & $903 \pm 70$ \\
\hline 9 & & $200 \pm 16$ & & $446 \pm 60$ \\
\hline 10 & & $795 \pm 64$ & & $874 \pm 49$ \\
\hline 11 & & $323 \pm 25$ & & $746 \pm 46$ \\
\hline 12 & + & $590 \pm 16$ & & $972 \pm 42$ \\
\hline Means \pm S.E. & & $558 \pm 65$ & & $940 \pm 62$ \\
\hline
\end{tabular}

1. Based upon 10 consecutive determinations commencing on day 150 of experiment.

2. $10 \mathrm{mg} / \mathrm{kg}$, given 15 minutes before measurement. 
TABLE 12. GENERALIZATION OF THE DISCRIMINÁTIVE STIMULUS PRODUCED BY MORPHINE $(10 \mathrm{mg} / \mathrm{kg})$ TO NARCOTIC DRUGS. 1

\begin{tabular}{|c|c|c|c|c|c|}
\hline \multirow[b]{2}{*}{ Drug } & \multirow[b]{2}{*}{$\begin{array}{c}\text { Dose } \\
(\mathrm{mg} / \mathrm{kg})\end{array}$} & \multirow[b]{2}{*}{$\mathrm{N}$} & \multirow{2}{*}{$\begin{array}{l}\quad \stackrel{8}{8} \\
\text { Selecting } \\
\text { Morphine } \\
\quad \text { Lever } \\
\end{array}$} & \multicolumn{2}{|c|}{$\begin{array}{l}\text { Responses on Unselected Lever } \\
\text { Before First Reinforcement } \\
\text { (Mean } \pm \text { S.E.) }\end{array}$} \\
\hline & & & & $\begin{array}{r}\text { Following Drug } \\
\text { Lever Selection }\end{array}$ & $\begin{array}{l}\text { Following Saline } \\
\text { Lever Selection }\end{array}$ \\
\hline \multirow[t]{5}{*}{ MORPH INE } & 0.64 & 5 & 20 & 0 & 0 \\
\hline & 1.25 & 5 & 0 & No drug selection & 0 \\
\hline & 2.50 & 17 & 47 * & 0 & $1.11+0.75$ (9) \\
\hline & 5.00 & 7 & 57 * & $1.50 \pm 1.19$ (4) & No saline selection \\
\hline & 10.00 & 12 & $100 *$ & 0 & No saline selection \\
\hline \multirow[t]{4}{*}{ CYCLAZOCINE } & 0.08 & 7 & 43 & $1.67+1.67 \quad(3)$ & $1.75+1.03 \quad(4)$ \\
\hline & 0.32 & 8 & 38 & $0.33 \pm 0.33 \quad(3)$ & 0 \\
\hline & 1.25 & 8 & $88^{*}$ & 0 & 0 \\
\hline & 2.50 & 5 & $80 *$ & $0.25 \pm 0.25 \quad(4)$ & 0 \\
\hline \multirow[t]{5}{*}{$\begin{array}{l}\text { ETHYLKETO- } \\
\text { CYCLAZOCINE }\end{array}$} & 0.08 & 5 & 0 & No drug selection & 0 \\
\hline & 0.16 & 10 & 10 & 0 & 0 \\
\hline & 0.32 & 7 & $71 *$ & $4.40 \pm 1.80 \quad(5)$ & 0 \\
\hline & 0.64 & 4 & 50 & $3.00 \pm 1.73$ (3) & 0 \\
\hline & 1.25 & 4 & 0 & No drug selection & 0 \\
\hline \multirow[t]{3}{*}{ NALOXONE } & 0.005 & 5 & 0 & No drug selection & 0 \\
\hline & 0.08 & 5 & 0 & No drug selection & $0.40 \pm 0.40 \quad(5)$ \\
\hline & 0.32 & 2 & 0 & No drug selection & 0 \\
\hline
\end{tabular}

1. All drugs and doses administered 15 minutes prior to testing.

* Statistically significant difference $(p<0.05)$ by Fisher Exact Probability in comparison with 1008 saline lever selection $(n=12)$. 
TABLE 13. ANTAGONISM OF DISCRIMINATIVE'STIMULUS PRODUCED BY MORPHINE $\left(10 \mathrm{mg} / \mathrm{kg}\right.$ ) BY NALOXONE ${ }^{1}$

\begin{tabular}{|c|c|c|c|c|c|c|}
\hline \multirow[b]{2}{*}{$\begin{array}{c}\text { Naloxone } \\
\text { Dose (mg/kg) }\end{array}$} & \multirow[b]{2}{*}{$\mathrm{N}$} & \multirow{2}{*}{$\begin{array}{l}\stackrel{8}{8} \\
\text { Selecting } \\
\text { Morphine } \\
\quad \text { Lever } \\
\end{array}$} & \multirow[b]{2}{*}{2} & \multicolumn{3}{|c|}{$\begin{array}{c}\text { Responses on Unselected Lever } \\
\text { Before First Reinforcement } \\
\text { (Mean } \pm \text { S.E. }\end{array}$} \\
\hline & & & & $\begin{array}{l}\text { Following Drug } \\
\text { Lever Selection }\end{array}$ & $\begin{array}{l}\text { Following } \\
\text { Lever Se }\end{array}$ & $\begin{array}{l}\text { Saline } \\
\text { lection }\end{array}$ \\
\hline 0 & 12 & $100 *$ & $6.891 *$ & 0 & No saline & selection \\
\hline 0.08 & 4 & $100 *$ & $4.701 *$ & 0 & No saline : & selection \\
\hline 0.16 & 5 & 60 & 2.761 & $1.67 \pm 1.20 \quad(3)$ & 0 & \\
\hline 0.32 & 6 & 0 & - & No drug selectio & on & \\
\hline
\end{tabular}

1. Naloxone administered 15 minutes prior to morphine (10 mg/kg).

* Statistically significant difference $(p<0.05)$ by Fisher Exact Probability in comparison to 1008 saline lever selection $(n=12)$. 
no injection prior to cyclazocine $(r=-0.98)$ (Table 14). Complete blockade was observed following naloxone $1.25 \mathrm{mg} / \mathrm{kg}$. Nonnarcotic psychoactive drugs which resulted in saline lever selection included d-butaclamol (0.16 mg/kg), l-butaclamol (0.16 mg/ $\mathrm{kg})$, d-amphetamine $(0.64 \mathrm{mg} / \mathrm{kg})$, haloperidol $(0.32 \mathrm{mg} / \mathrm{kg})$, chlorpromazine $(10 \mathrm{mg} / \mathrm{kg})$ and clonidine $(0.16$ $\mathrm{mg} / \mathrm{kg}$ ) (Table 15).

H. The Effects of Neuroleptics Upon the Morphine Discriminative Stimulus

The butyrophenone neuroleptic, haloperidol, when administered at a dose of $0.32 \mathrm{mg} / \mathrm{kg}, 60$ minutes prior to morphine injection, produced a statistically significant decrease in the percent animals selecting drug lever following morphine at doses of 2.5 and $10 \mathrm{mg} / \mathrm{kg}$ when compared to saline pretreatment before morphine at these doses (Table 16) .

Attenuation of the morphine discriminative stimulus was not observed following pretreatment with the neuroleptics d-butaclamol $(0.16 \mathrm{mg} / \mathrm{kg})$, l-butaclamol $(0.16 \mathrm{mg} / \mathrm{kg})$ and clozapine $(2.5 \mathrm{mg} / \mathrm{kg})$.

Following pretreatment with chlorpromazine $(10 \mathrm{mg} / \mathrm{kg})$ and declamol $(0.16 \mathrm{mg} / \mathrm{kg})$, animals were unable to respond due to sedation .

I. Cyclazocine Analgesia - Mouse Tail Flick

Cyclazocine was tested for analgesia at doses of 2.5 $\mathrm{mg} / \mathrm{kg}$ and $5.0 \mathrm{mg} / \mathrm{kg}$. At the smaller dose of cyclazocine, 20\% 
TABLE 14. ANTAGONISM OF MORPHINE DISCRIMINATIVE STIMULUS GENERALIZATION TO CYCLAZOCINE $(1.25 \mathrm{mg} / \mathrm{kg})$ BY NALOXONE ${ }^{1}$

\begin{tabular}{|c|c|c|c|c|c|}
\hline \multirow[b]{2}{*}{$\begin{array}{c}\text { Naloxone } \\
\text { Dose (mg/kg) }\end{array}$} & \multirow[b]{2}{*}{$\mathbf{N}$} & \multirow{2}{*}{$\begin{array}{l}\text { : } \\
\text { Selecting } \\
\text { Morphine } \\
\text { Lever } \\
\end{array}$} & \multicolumn{3}{|c|}{$\begin{array}{l}\text { Responses on Unselected Lever } \\
\text { Before First Reinforcement } \\
\text { (Mean } \pm \text { S.E.) }\end{array}$} \\
\hline & & & $\begin{array}{r}\text { Following Drug } \\
\text { Lever Selection } \\
\end{array}$ & $\begin{array}{l}\text { Following } \\
\text { Lever Sel }\end{array}$ & $\begin{array}{l}\text { Saline } \\
\text { lection }\end{array}$ \\
\hline 0 & 8 & $88 *$ & 0 & & 0 \\
\hline 0.08 & 4 & $100 *$ & 0 & No saline & selection \\
\hline 0.32 & 6 & 33 & 0 & & 0 \\
\hline 1.25 & 6 & 0 & No drug selection & & 0 \\
\hline
\end{tabular}

1. Naloxone administered 15 minutes prior to cyclazocine $(1.25 \mathrm{mg} / \mathrm{kg})$

* Statistically significant difference ( $p<0.05)$ by Fisher Exact Probability in comparison with $100 \%$ saline lever selection $(n=12)$. 
TABLE 15. GENERALIZATION OF THE DISCRIMINATIVE STIMULUS PRODUCED BY MORPHINE $(10 \mathrm{mg} / \mathrm{kg})$ TO NON-NARCOTIC PSYCHOACTIVE DRUGS

\begin{tabular}{|c|c|c|c|c|c|}
\hline \multirow[b]{2}{*}{ Drug } & \multirow[b]{2}{*}{ Dose } & \multirow[b]{2}{*}{$\underline{\mathbf{N}}$} & \multirow{2}{*}{$\begin{array}{l}\quad \stackrel{8}{\text { Selection }} \\
\text { Morphine } \\
\text { Lever } \\
\end{array}$} & \multicolumn{2}{|c|}{$\begin{array}{l}\text { Responses on Unselected Lever } \\
\text { Before First Reinforcement } \\
\text { (Mean } \pm \text { S.E.) }\end{array}$} \\
\hline & & & & $\begin{array}{r}\text { Following Drug } \\
\text { Lever Selection } \\
\end{array}$ & $\begin{array}{l}\text { Following Saline } \\
\text { Lever Selection }\end{array}$ \\
\hline d-BUTACLAMOL & 0.16 & 4 & 0 & No drug selection & 0 \\
\hline 1-BUTACLAMOL & 0.16 & 6 & 0 & No drug selection & 0 \\
\hline d-AMPHETAMINE & 0.64 & 4 & 0 & No drug selection & $0.75+0.75 \quad(4)$ \\
\hline HALOPERIDOL & 0.32 & 8 & 0 & No drug selection & $0.63+0.50 \quad(8)$ \\
\hline CLONIDINE & 0.16 & 4 & 25 & 0 & $3.00+3.00 \quad(3)$ \\
\hline
\end{tabular}


TABLE 16. THE EFFECTS OF HALOPERIDOL PRETREATMENT ${ }^{1}$ UPON THE DISCRIMINATE STIMULUS PRODUCED BY MORPHINE $(10 \mathrm{mg} / \mathrm{kg})$

\begin{tabular}{|c|c|c|c|c|c|}
\hline \multirow[b]{2}{*}{$\begin{array}{l}\text { Haloperidol } \\
\text { Dose (mg/kg) }\end{array}$} & \multirow{2}{*}{$\begin{array}{l}\text { Morphine } \\
\text { Dose } \\
\text { (mg/kg) }\end{array}$} & \multirow[b]{2}{*}{$\underline{\mathbf{N}}$} & \multirow{2}{*}{$\begin{array}{c}\% \\
\text { Selecting } \\
\text { Morphine } \\
\text { Lever } \\
\end{array}$} & \multicolumn{2}{|c|}{$\begin{array}{l}\text { Responses on Unselected Lever } \\
\text { Before First Reinforcement } \\
\text { (Mean } \pm \text { S.E.) }\end{array}$} \\
\hline & & & & $\begin{array}{r}\text { Following Drug } \\
\text { Lever Selection } \\
\end{array}$ & $\begin{array}{l}\text { Following Saline } \\
\text { Lever Selection }\end{array}$ \\
\hline 0 & 2.50 & 17 & $47 *$ & 0 & $5.00 \pm 1.00$ (2) \\
\hline 0 & 10.00 & 12 & $100 *$ & 0 & - \\
\hline 0.32 & 2.50 & 16 & 13 & 0 & $6.00 \pm 3.01(2)$ \\
\hline 0.32 & 10.00 & 7 & 57 & 0 & $1.00 \pm 0(1)$ \\
\hline
\end{tabular}

1. Haloperidol administered one hour prior to morphine.

* Statistically significant difference $(p \leq 0.05)$ by Fisher Exact Probability in comparison to saline pretreatment. 
of the animals tested were analgesic at five minutes post injection and $10 \%$ were analgesic at 35 . minutes post injection $(\mathrm{n}=10)$. A dose of $5.0 \mathrm{mg} / \mathrm{kg}$ cyclazocine produced analgesia in $58 \%$ of animals tested five minutes following injection and $32 \%$ of the animals tested 35 minutes following injection ( $n=19)$ (Table 17).

The analgesic properties of cyclazocine were antagonized by the narcotic antagonist, naloxone (10 mg/kg) (Table 17).

J. The Effects of Neuroleptic Pretreatment Upon Cyclazocine Analgesia

Oxiperomide $(0.64 \mathrm{mg} / \mathrm{kg})$, administered one hour prior to cyclazocine $(2.5 \mathrm{mg} / \mathrm{kg})$, produced a significant increase in the percent animals with analgesic latencies 35 minutes after cyclazocine injection as compared to groups of animals receiving saline pretreatment (Table 18). In saline pretreated animals, cyclazocine $(2.5 \mathrm{mg} / \mathrm{kg}$ ) administration in $20 \%$ animals tested having analgesic latencies five minutes after cyclazocine while $10 \%$ of the animals had analgesic latencies after 35 minutes $(n=10)$. In animals receiving oxiperomide $(0.64 \mathrm{mg} / \mathrm{kg})$ pretreatment, $89 \%$ of the animals had analgesic latencies five minutes after cyclazocine while $100 \%$ of these animals had analgesic latencies 35 minutes after injection $(n=9)$. Oxiperomide administered alone does not produce analgesia.

Clozapine $(2.5 \mathrm{mg} / \mathrm{kg})$, administered 30 minutes prior to cyclazocine $(2.5 \mathrm{mg} / \mathrm{kg})$, produced a potentiation of the 
TABLE 17. THE EFFECTS OF NALOXONE ${ }^{1}$ UPON CYCLAZOCINE ANALGESIA USING MOUSE TAIL FLICK PROCEDURE

\begin{tabular}{|c|c|c|c|c|}
\hline $\begin{array}{c}\text { Naloxone } \\
\text { nose }(\mathrm{mg} / \mathrm{kg})\end{array}$ & $\begin{array}{l}\text { Cyclazocine } \\
\text { Dose }(\mathrm{mg} / \mathrm{kg})\end{array}$ & $\mathbf{N}$ & 5 Minutes & 35 Minutes \\
\hline 0 & 2.50 & 10 & 20 & 10 \\
\hline 0 & 5.00 & 19 & 58 & 32 \\
\hline 10 & 2.50 & 10 & 0 & 0 \\
\hline 10 & 5.00 & 8 & 0 & 0 \\
\hline
\end{tabular}

1. Naloxone administered 10 minutes prior to cyclazocine.

2. Analgesic latencies exceed group control mean by three standard deviations or more. 
TABLE 18. THE EFFECTS OF NEUROLEPTIC PRETREATMENT UPON CYCLAZONE ANALGESIA

\begin{tabular}{|c|c|c|c|c|c|c|}
\hline \multirow[b]{2}{*}{ Drug } & \multirow[b]{2}{*}{ Dose $(\mathrm{mg} / \mathrm{kg})$} & \multirow[b]{2}{*}{ Time } & \multirow[b]{2}{*}{ (Minutes } & \multirow[b]{2}{*}{$\mathrm{N}$} & \multicolumn{2}{|c|}{ \& Analgesia 1} \\
\hline & & & & & 5 Minutes & 35 Minutes \\
\hline SALINE & - & & 60 & 10 & 20 & 10 \\
\hline \multirow[t]{3}{*}{ OXIPEROMIDE } & 0.04 & & 60 & 8 & 12 & 38 \\
\hline & 0.16 & & 60 & 8 & 50 & 0 \\
\hline & 0.64 & & 60 & 9 & 89 & $100 *$ \\
\hline \multirow[t]{4}{*}{ HALOPERIDOL } & 0.04 & & 60 & 5 & 40 & 20 \\
\hline & 0.08 & & 60 & 10 & 90 & 60 \\
\hline & 0.64 & & 60 & 14 & 79 & 67 \\
\hline & 2.50 & & 60 & 8 & 38 & 75 \\
\hline \multirow[t]{2}{*}{ DEXCLAMOL } & 0.04 & & 60 & 9 & 44 & 67 \\
\hline & 0.16 & & 60 & 9 & 78 & 44 \\
\hline \multirow[t]{3}{*}{ PIPAMPERONE } & 0.64 & & 60 & 8 & 38 & 38 \\
\hline & 2.50 & & 60 & 10 & 60 & 40 \\
\hline & 10.00 & & 60 & 7 & 72 & 86 * \\
\hline \multirow[t]{3}{*}{ CLOZAPINE } & 0.64 & & 30 & 9 & 22 & 11 \\
\hline & 1.25 & & 30 & 10 & 50 & 30 \\
\hline & 2.50 & & 30 & 9 & 67 & $100 *$ \\
\hline \multirow[t]{2}{*}{ HALOPOMIDE } & 0.16 & & 60 & 11 & 36 & 36 \\
\hline & 0.64 & & 60 & 10 & 20 & 40 \\
\hline 1-BUTACLAMOL & 0.16 & & 60 & 10 & 40 & 20 \\
\hline ACEPERONE & 10.00 & & 60 & 10 & 30 & 30 \\
\hline
\end{tabular}

1. Analgesic latencies exceed the group control mean by three standard deviations or more. 
analgesic potency of cyclazocine 35 minutes after cyclazocine administration (Table 18). Clozapine administered alone does not produce analgesia.

Increases in percent animals with analgesic readings were observed following pretreatment with haloperidol $10.08,0.64$, and $2.5 \mathrm{mg} / \mathrm{kg})$ and dexclamol $(0.16 \mathrm{mg} / \mathrm{kg})$, but these changes were not statistically significant (Table 18).

No change in the analgesic potency of cyclazocine was evident following pretreatment with halopomide $(0.16$ and 0.64 $\mathrm{mg} / \mathrm{kg}), 1$-butaclamol $(0.16 \mathrm{mg} / \mathrm{kg})$ or aceperone $(10 \mathrm{mg} / \mathrm{kg})$. 
v. DISCUSSION

In agreement with other recent reports (Hirschhorn, 1977; Rosecrans et al., 1978; Teal and Holtzman, 1980), the narcotic agonist-antagonist cyclazocine has been shown to produce a discriminative stimulus capable of controlling operant responding in the rat. The results described indicate that these effects are specific to cyclazocine and that they are substantially, but not exclusively, based on narcotic-like actions of cyclazocine.

The specificity of the discriminative stimulus produced by cyclazocine is demonstrated by the dose dependent nature of lever selection in animals trained to discriminate cyclazocine from saline. The drug specificity of these effects is also seen in the dose dependent nature of generalization of the cyclazocine discriminative stimulus to other narcotic drugs.

The discriminative stimulus produced by cyclazocine was found to be completely blocked by the pure narcotic antagonist naloxone, suggesting that the discriminative stimulus produced by cyclazocine is mediated by activity at central opiate receptors. Cyclazocine discriminative stimulus production at central opiate receptors is also suggested by the nature of the stimulus generalization which were observed in these experiments. Complete generalization of the cyclazocine discriminative stimulus to other narcotic drugs. 
The discriminative stimulus produced by cyclazocine was found to be completely blocked by the pure narcotic antagonist naloxone, suggesting that the discriminative stimulus produced by cyclazocine is mediated by activity at central opiate receptors. Cyclazocine discriminative stimulus production at central opiate receptors is also suggested by the nature of the stimulus generalization which were observed in these experiments. Complete generalization of the cyclazocine discriminative stimulus was observed to all narcotic agonists and antagonists tested with the exception of $\mathrm{U}-49,274 \mathrm{~A}$ and $\mathrm{U}-50,788 \mathrm{E}$ while generalization testing with non-narcotic psychoactive drugs resulted in nearly exclusive saline lever selection.

Although the central activity of cyclazocine was narcotic in nature, certain portions of the results indicate that the discriminative stimulus produced by cyclazocine may differ from that produced by the pure narcotic agonist morphine. Both the cyclazocine discriminative stimulus and the morphine discriminative stimulus were reversed by the narcotic antagonist naloxone. Similarly, generalization of each of these drugs to the other was antagonized by naloxone. The dose of naloxone required to antagonize the effects of cyclazocine far exceeded that required to antagonize morphine. A mechanism for such a difference is not readily apparent from the present results however it is noteworthy that a similar difference in naloxone sensitivity between cyclazocine like drugs and morphine has been observed in previous discriminative stimulus studies 
(Hirschhorn, 1977; Rosecrans et al., 1978; Teal and Holtzman, 1980) and animal behavior studies (Buckett and Shaw, 1975; Tepper and Woods, 1978).

The nature in which cyclazocine and morphine generalized to ethylketocyclazocine further suggest a difference in the effects produced by cyclazocine and morphine. In the case of cyclazocine, ethylketocyclazocine generalization was a uniformly increasing dose dependent effect. In the morphine generalization experiments, it was found that ethylketocyclazocine generalization approximated a bell shaped curbe with the highest dose tested resulting in $100 \%$ saline lever selection. It is apparent that the generalization to ethylketocyclazocine by cyclazocine and morphine is different suggesting differences in central binding characteristics.

An interesting aspect of the bell shaped morphine generalization to ethylketocyclazocine is that it closely approximated the nature of the subjective effects produced in humans by narcotic agonist-antagonist when compared to morphine. It has been shown that human addicts identify low doses of narcotic agonist-antagonists as morphine like while higher doses tend to produce effects unlike morphine such as dysphoria and hallucinations (Martin et al., 1965).

Teal and Holtzman (1980) recently showed that the generalization of cyclazocine to phencyclidine and ketamine, two nonopioid drugs, was not subject to naloxone antagonism. The present results indicate that the generalization of cyclazocine to the narcotic agonist-antagonist nalorphine also is not 
completely antagonized by naloxone. These results suggest that a non-narcotic component of the activities of the narcotic agonist-antagonists may be partially responsible for the production of their discriminative stimuli and suggests a qualitative difference in the central effects of the pure narcotic agonists such as morphine and the narcotic agonist-antagonists such as cyclazocine.

Many of the observed differences between cyclazocine and morphine may be explained in terms of a difference in affinities of these drugs for a single opiate receptor. An alternative explanation is that the observed differences may be due to differential activities at different types of narcotic receptors which have recently been described (Martin et al., 1976; Gilbert and Martin, 1976). Within this system, morphine and cyclazocine are proposed to have different affinities and activities at three heterogeneous opiate receptors. The present results and many other results describing differences between cyclazocine and morphine are consistent with a multireceptor theory, however, the actual existence of these receptors has not been substantiated in all species, requiring caution in interpreting results in terms of multiple opiate receptors.

A large body of literature exists describing the role of dopamine in the central activity of narcotic analgesics (for review see Lal, 1975). The present results demonstrate that dopamine also plays a role in the production of the discriminative stimulus properties of narcotic analgesics. Haloperidol, 
benperidol and d-butaclamol, neuroleptic drugs with dopamine receptor blocking properties, all caused an attenuation of the cyclazocine discriminative stimulus while haloperidol also blocked the stimulus strength of morphine. Since this effect was observed in the stimuli produced by the pure narcotic agonist as well as the narcotic agonist-antagonists, it is reasonable to assume that the dopamine activity which is present is common to both types of narcotic agents and is not a predominent factor responsible for the observed differences between morphine and cyclazocine.

Although neuroleptic pretreatment caused a diminished discriminative stimulus strength of cyclazocine and morphine, neuroleptic pretreatment produced a potentiation of cyclazocine analgesia in these experiments. Previous results (Head et al., 1979) showed that neuroleptic pretreatment caused a potentiation of morphine analgesia. Again, cyclazocine and morphine are effected in a similar fashion by neuroleptic pretreatment suggesting a similar dopamine role in the central activities of each of these drugs.

The attenuating effects neuroleptics had upon the cyclazocine and morphine discriminative stimuli when compared with the potentiating effects neuroleptics had upon cyclazocine and morphine analgesia show that the discriminative stimuli produced by these drugs are not based upon the analgesic properties of these drugs. If in fact the stimulus properties were based upon analgesia, one would expect either exclusive potentiation or exclusive attenuation of these properties following neuroleptic pretreatment. 


\section{CONCLUSION}

The experiments which have been described demonstrate that the narcotic agonist-antagonist cyclazocine produces a discriminative stimulus in the laboratory rat. In light of its naloxone reversability and generalization to other narcntic drugs, it is suggested that the cyclazocine discriminative stimulus is principally produced by activity at central opiate receptors. The cyclazocine discriminative stimulus was subject to attenuation following neuroleptic pretreatment indicating that an additional component of the cyclazocine discriminative stimulus is dopaminergic in nature.

Similarities between the cyclazocine discriminative stimulus and the discriminative stimulus produced by the pure narcotic agonist morphine were seen in that the morphine discriminative stimulus was also subject to naloxone antagonism and neuroleptic attenuatior.

Although the cyclazocine discriminative stimulus was shown to be morphine like as described above, portions of the results also indicate that the cyclazocine discriminative stimulus differed from the morphine discriminative stimulus. Cyclazocine was shown to be much less sensitive to naloxone antagonism than was morphine. In addition, the generalization of cyclazocine and morphine to ethylketocyclazocine were found to differ markedly. 
These experiments have also demonstrated that the cyclazocine discriminative stimulus is not based upon the analgesic properties of the drug. While the discriminative stimulus was partially blocked by neuroleptic pretreatment, the analgesic properties of cyclazocine were potentiated by neuroleptic pretreatment. In light of previous experimentation which demonstrated that morphine analgesia was potentiated by haloperidol (Head et al., 1979), the present finding of haloperidol attenuation of the morphine discriminative stimulus indicates that the morphine discriminative stimulus is not based upon the analgesic properties of morphine. 


\section{BIBLIOGRAPHY}

Adam-Carrière, D., Merali, Z, and Stretch: Effects of morphine, naloxone, d,l-cyclazocine and d-amphetamine on behavior controlled by a schedule of interresponse time reinforcement. Can. J. Physiol. Pharmacol. 56, 707-720, 1978.

Appel, J.B., Kuhn, D.M. and White, F.J.: vual receptor mediation of the discriminative stimulus properties of pentazocine. In: Drug Discrimination and State Dependent Learning, ed. by B.T. Ho, Daniel W. Richards III, Douglas L. Chute, pp. 149-162, Academic Press, New York, 1978.

Beaumont, A. and Hughes, J.: Biology of opioid peptides. Ann. Rev. Pharmacol. 19, 245-267, 1979 .

Buckett, W.R. and Shaw, J.S.: Dopaminergic drugs antagonize the psychotomimetic effects of partial agonist-antagonists. Psychopharm. 42, 293-297, 1975.

Chang, K.J. and Cuatrecasas, P.: Multiple opiate receptorsenkephalin and morphine bind to receptors of different specificity. J. Biol. Chem. 254, 2610-2618, 1979 .

Chappel, J.N., Jaffe, J.H., and Senay, E.F.: A controlled study using cyclazocine in the treatment of narcotic addiction. Am. J. Drug and Alcohol Abuse, 1, 233-242, 1974.

Colpaert, F.C.: Narcotic cue and narcotic state. Life Sci. 20, 1097-1108, 1977.

Colpaert, F.C., Lal, H., Niemegeers, C.J.E. and Janssen, P.A. J.: Investigations on drug produced and subjectively experienced discriminative stimulus. I. The fentanyl cue, a tool to investigate subjectively experienced narcotic drug actions. Life Sci. 16, 705-716, 1975.

Colpaert, F.C., Niemegeers, C.J.E. and Janssen, P.A.J.: Effects of alpha-methyl paratyrosine, adrenolytic compounds, pimozice and other neuroleptics on the narcotic cue. Arch. Int. Pharmacodyn. 225, 308-316, 1977.

Colpaert, F.C., Niemegeers, C.J.E. and Janssen, P.A.J.: Fentanyl and apomorphine; asymmetrical generalization of discriminative stimulus properties. Neuropharm. 15, 541-545,

1976. 
Dewey, W.L. and Harris, L.S.: Antinociceptive activity of the narcotic antagonist analgesics and antagonistic activity of narcotic analgesics in rodents. J.'Pharm. Exp. Ther. 179, $652-659,1971$.

Dewey, W.L., Harris, L.S., Howes, J.F. and Nuite, J.A.: The effect of various neurohumoral modulators on the activity of morphine and the narcotic antagonists in the tail flick and phenylquinone tests. J. Pharm. Exp. Ther. 175, 435-442, 1970 .

Dewey, W.L., Snyder, J.W., Harris, L.S. and Howes, J.F.: The effect of narcotic antagonists on the tail flick response in spinal mice. J. Pharm. Pharmac. 21, 548-550, 1969.

Eddy, N.B., Hallach, H., Isabell, H. and Seevers, M.H.: Drug dependence: Its significance and characteristics. In: Drug Abuse, Data and Debate, ed. by P.H. Blaekey, Thomas, Springfield, 1970.

Frazer, H.F., Van Horn, G.D., Martin, W.R., Wolbach, A.B. and Isabell, H.: Methods for evaluating addiction liability. (A) "Attitude" of opiate addicts toward opiate-like drugs; (B) A short term "direct addiction test." J. Pharm. Exp. Ther. 133, $371-387,1961$.

Freedman, A.M., Fink,.M., Sharoef, R., Zaks, A.: Clinical studies of cyclazocine in the treatment of narcotic addiction. Amer. J. Psychiat. 124, 57-62, 1968 .

Gianutsos, G. and Lal, H.: Effects of loperamide, haloperidol and methadone in rats trained to discriminate morphine from saline. Psychopharm. 41, 267-270, 1975.

Gianutsos, G. and Lal, H.: Selective interaction of drugs with a discriminable stimulus associated with narcotic action. Life Sci. 19, 91-98, 1976.

Gilbert, P.E. and Martin, W.R.: A comparison of morphine and cyclazocine physical dependence in chronic spinal dogs. Fed. Proc. $35,470,1976$.

Gilbert, P.E. and Martin, W.R.: The effects of morphine and nalorphine-like drugs in the nondependent, morphine-dependent and cyclazocine-dependent chronic spinal dog. J. Pharm. Exp. Ther. $198,66-82,1976$.

Haertzen, C.A.: Subjective effects of narcotic antagonists cyclazocine and nalorphine on the Addiction Research Center Inventory (ARCI). Psychopharm. 18, 366-377, 1970 .

Harris, L.S., Dewey, W.L., Howes, J.F., Kennedy, J.S. and Pars, H.: Narcotic antagonist analgesics: interaction with cholinergic systems. J. Pharm. Exp. Ther., 169, 17-22, 1969. 
Harris, L.S. and Pierson, A.K.: Some narcotic antagonists in the benzomorphan series. J. Pharm. Exp. Ther. 143, 141- 148 1964.

Head, M., Lal, H., Puri, S., Mantione, C. and Valentino, D.: Enhancement of morphine analgesia after acute and chronic haloperidol. Life Sci.,24, 2037-2043, 1979.

Hiller, J.M. and Simon, E.J.: ${ }^{3}$ H-ethylketocyclazocine binding - lack of evidence for a separate k-receptor in rat CNS. Eur. J. Pharm. 60, 389-390, 1979.

Hirschhorn, I.D.: Pentazocine, cyclazocine and nalorphine as discriminative stimuli. Psychopharm. 54, 289-294, 1977.

Hirschhorn, I.D. and Rosecrans, J.A.: Generalization of morphine and lysergic acid diethylamide (ISD) stimulus properties to narcotic analgesics. Psychopharm. 47, 65-69, 1976.

Holzman, S.G.: Effects of morphine and narcotic antagonists on avoidance behavior of the squirrel monkey. J. Pharm. Exp. Ther. 196, 145-155, 1976.

Holtzman, S.G. and Jewett, R.E.: Some actions of pentazocine on behavior and brain monoamines in the rat. J. Pharm. Exp. Ther. 181, 346-356, 1972 .

Holtzman, S.G. and Jewett,R.E.: Stimulation of behavior in the rat by cyclazocine: Effects of naloxone. J. Pharm. Exp. Ther. 187, 380-390, 1973.

Hutchinson, M., Kosterlitz, H.W., Leslie, F.M., Waterfield, A.A. and Terenius, L.: Assessment in the guinea pig ileum and mouse vas deferens of benzomorphans which have strong antinociceptive activity but do not substitute for morphine in the dependent monkey. Br. Jour. Pharm. 55, 541-546, 1975.

Jaffe, J.H. and Martin, W.R.: Narcotic analgesics and antagonists. In: The Pharmacological Basis of Therapeutics, ed. by Louis S. Goodman and Alfred Gilman. pp. 245-283. McMillan Publ. Co., Inc., New York, 1975.

Jasinski, D.R., Martin, W.R. and Sapira, J.D.: Antagonism of the subjective, behavioral, pupillary and respiratory depressant effects of cyclazocine by naloxone. Clin. Pharmacol. and Ther. $9,215-222,1968$.

Kleber, H., Kinsella, J.K.., RIordan, C., Greaves, S. and Sweeney, D.: The use of cyclazocine in treating narcotic addicts in a low-intervention setting. Arch. Gen. Psychiatry $30,37-42,1974$. 
Kuhn, D.M., Greenberg, I. and Appel, J.B.: Stimulus properties of the narcotic antagonist pentazocine: similarity to morphine and antagonism by naloxone.. J. Pharm. Exp. Ther. $196,121-127,1976$.

Lal, H.: Narcotic dependence, narcotic action and dopamine receptors. Life Sci. 17, 483-496, 1975.

Lal, H., Gianutsos, G. and Miksic, S.: Discriminable stimulus produced by analgesics. In: Discriminative Stimulus Properties of Drugs, ed. by H. Lal, pp. 23-46. Plenum Press, New York, 1977.

Lasagna, L., DeKornfield, T.J., and Pierson, J.W.: The analgesic efficacy and respiratory effects in man of a benzomorphen "narcotic antagonist." J. Pharm. Exp. Ther. 144, 12-16, 1964.

Laskowitz, D., Brill, L. and Jaffe, J.H.: Cyclazocine intervention in the treatment of narcotic addiction: another look, In: Opiate Addiction, Origins and Treatments, ed. by $\mathrm{S}$. Fisher and A.M. Freedman, pp. 221-230, Winston, Washington, D.C., 1972 .

Lord, J.A.H., Waterfield, A.A., Hughes, J. and Kosterlitz, H.W.: Endogenous opioid peptides: multiple agonists and receptors. Nature 267, 495-499, 1977.

Lord, J.A.H., Waterfield, A.A., Hughes, J. and Kosterlitz, H.W.: In: Opiates and Endogenous Opioid Peptides. Ed. by H.W. Kosterlitz, pp. 275-280, North-Holland, Amsterdam, 1976.

McMillan, D.E. and Harris, L.S.: Behavioral and morphineantagonist effects of the optical isomers of pentazocine and cyclazocine. J. Pharm. Exp. Ther. 180, 269-279, 1972.

Martin, W.R.: Opioid Antagonists. Pharmacological Reviews $19,463-521,1967$.

Martin, W.R., Eades, C.G., Thompson, J.A., Huppler, R.E. and Gilbert, P.E.: The effects of morphine- and nalorphine-like drugs in the nondependent and morphine-dependent chronic spinal dog. J. Pharm. Exp. Ther. 197, 517-532, 1976.

Martin, W.R., Fraser, H.F., Gorodetsky, C.W. and Rosenbery, D.E.: Studies of the dependence-producing potential of the narcotic antagonist 2-cyclo propyl methyl,-2'hydroxy-5,9dimethyl-6,7-benzomorphan (cyclazocine, WIN 20,740, ARCIIC3). J. Pharm. Exp. Ther. 150, 426-436, 1965.

Martin, W.R., Gilbert, P.E. and Thompson, J.A.: Tolerance to and dependence on $\mathrm{N}$-allyl-normetazocine in the chronic spinal dog. Fed. Proc. 38, 587, 1979. 
Martin, W.R., Gorodetzky, C.W. and MCClane, T.K.: An experimental study in the treatment of narcotic addicts with cyclazocine. Clin. Pharm. and Ther. $\underline{7}, 455-465,1966$.

Miksic, S. and Lal, H.: Tolerance to morphine produced discriminative stimuli and analgesia. Psychopharm. 54, 217-221, 1977.

Miksic, S., Shearman, G., and Lal, H.: Generalization study with some narcotic and non-narcotic drugs in rats trained for morphine-saline discrimination. Psychopharm. 60, 103-104, 1978.

Niemegeers, C.J., Lenaerts, F.M. and Janssen, P.A.J.: Loeramide (R-18553): A novel antidiarrheal agent. 2. In vivo parenteral pharmacology and acute toxicity in mice. Comparison with morphine, codeine and diphenoxylate. Arznei-For. 24 , 1636,1974 .

Olds, J. and Travis, R.P.: Effects of chlorpromazine, meprobamate, pentobarbital and morphine on self-administration. J. Pharm. Exp. Ther. 128, 397-404, 1960 .

Pert, C. and Snyder, S.: Opiate receptor binding of agonists and antagonists affected differentially by sodium. Mol. Pharm. $10,868-879,1974$.

Pickworth, W.B. and Sharpe, L.G.: EEG-behavioral dissociation after morphine- and cyclazocine-like drugs in the dog. Further evidence for two opiate receptors. Neuropharm. 18, $617-623,1979$.

Resnick, R.B., Fink, M. and Freedman, A.M.: Cyclazocine treatment of opiate dependence: A progress report. In: Progress in Psychiatric Drug Treatment, ed. by D.F. Klein, R. Gittleman Klein, pp. 992-1004, Brunner/Mozel, New York, 1976.

Resnick, R., Fink, M. and Freedman, A.M.: High-dose cyclazocine therapy of opiate dependence. Am. J. Psychiatry 131 , 595-599, 1974 .

Resnick, R.B., Schuyten-Resnick, E. and Washton, A.M.: Assessment of narcotic antagonists in the treatment of opioid dependence. Ann. Rev. Pharm. 20, 463-474, 1980.

Rosecrans, J.A., Chance, W.T. and Spencer, R.M.: The discriminative stimulus properties of cyclazocine: generalization studies involving nalorphine, morphine and LSD. Res. Comm. in Chem. Path. and Pharmacol. 20, 221-237, 1978

Schaefer, G.J. and Holtzman, S.G.: Discriminative effects of cyclazocine in the squirrel monkey. J. Pharm. Exp. Ter. 205, 291-301, 1978 . 
Schneider, C.: Behavioral effects of some morphine antagonists and hallucinogens in the rat. Nature 220, 586-587, 1968.

Sewell, R.D.E. and Spencer, P.S.J.: Anti-nociceptive activity of narcotic agonists and partial agonists in mice given biogenic amines by intracerebroventricular injection. Psychopharm. $42,67-71,1975$.

Shannon, H.E. and Holtzman, S.G.: Evaluation of discriminative effects of morphine in the rat. J. Pharm. Exp. Ther. 198, $54-65$, 1976.

Shannon, H.E. and Holtzman, S.G.: Further evaluation of the discriminative effects of morphine in the rat. J. Pharm. Exp. Ther. 201, 55-66, 1977 .

Shannon, H.E. and Holtzman, S.G.: Morphine training dose: A determinant of stimulus generalization to narcotic antagonists in the rat. Psychopharm. 61, 239-244, 1979.

Simon, E.J. and Groth, J.: Kinetics of opiate receptor inactivation by sulfhydryl reagents: evidence for conformational change in the presence of sodium. Proc. Natl. Acad. Sci. 72, 2404-2407, 1975 .

Simon, E.J., Hiller, J.M. and Edelman, I.: Stereospecific binding of the potent narcotic analgesic ${ }^{3} \mathrm{H}$-etorphine to rat brain homogenates. Proc. Natl. Acad. Sci. 70, 1947-1949, 1973.

Smith, A.P. and Loh, H.H.: Heterogenicity of opiate receptor interaction. Pharmacology 20, 57-63, 1980.

Stokbroekx, R.A., Vandenberg, J., Heertum, A.H.M.T., Laar, G.M.L.W., Van Der Aa, M.J.M., Van Bever, W.F.M. and Janssen, P.A.J.: Synthetic antidiarrheal agents. 2. 2-diphenyl-R (4'-aryl-4'-hydroxy-piperidine)butyramides. J. Med. Chem. 16 , $782-786,1973$.

Teal, J.J. and Holtzman, S.G.: The discriminative stimulus effects of cyclazocine in the rat. Fed. Proc. 38, 741, 1979.

Teal, J.J. and Holtzman, S.G.: Discriminative stimulus effects of cyclazocine in the rat: J. Pharm. Exp. Ther. 212, $368-376,1980$.

Teiger, D.G.: A test for antinociceptive activity of narcotic and narcotic antagonist analgesics in the guinea pig. J. Pharm. Exp. Ther. 197, 311-316, 1976.

Tepper, P. and Woods, J.: Changes in locomotor activity and naloxone induced jumping in mice produced by WIN-35, 197-2 and morphine. Psychopharm. 58, 125-129, 1978. 
Terenius, I.: Stereospecific interaction between narcotic analgesics and a synaptic plasma membrane fraction of rat cerebral cortex. Acta Pharm. and Tox. 32, 317-320, 1973.

Wray, S.R.: A correlative evaluation of cyclazocine, LSD and naloxone on continuous avoidance in rats. Psychopharm. 26, 29-43, 1972 . 